\title{
Syn-metamorphic sulfidation of the Gamsberg zinc deposit, South Africa
}

\author{
Stefan Höhn ${ }^{1}(1) \cdot$ Hartwig E. Frimmel ${ }^{1,2} \cdot$ Westley Price ${ }^{3}$
}

Received: 25 October 2020 / Accepted: 15 August 2021 / Published online: 6 September 2021

(c) The Author(s) 2021

\begin{abstract}
The Mesoproterozoic Aggeneys-Gamsberg ore district, South Africa, is one of the world's largest sulfidic base metal concentrations and well-known as a prime example of Broken Hill-type base metal deposits, traditionally interpreted as metamorphosed SEDEX deposits. Within this district, the Gamsberg deposit stands out for its huge size and strongly Zn-dominated ore ( $>14 \mathrm{Mt}$ contained $\mathrm{Zn}$ ). New electron microprobe analyses and element abundance maps of sulfides and silicates point to fluid-driven sulfidation during retrograde metamorphism. Differences in the chemistry of sulfide inclusions within zoned garnet grains reflect different degrees of interaction of sulfides with high metal/sulfur-ratio with a sulfur-rich metamorphic fluid. Independent evidence of sulfidation during retrograde metamorphism comes from graphic-textured sulfide aggregates that previously have been interpreted as quenched sulfidic melts, replacement of pyrrhotite by pyrite along microfractures, and sulfides in phyllic alteration zones. Limited availability of fluid under retrograde conditions caused locally different degrees of segregation of $\mathrm{Fe}$-rich sphalerite into $\mathrm{Zn}$-rich sphalerite and pyrite, and thus considerable heterogeneity in sphalerite chemistry. The invoked sulfur-rich metamorphic fluids would have been able to sulfidize base metal-rich zones in the whole deposit and thus camouflage a potential pre-metamorphic oxidation. These findings support the recently established hypothesis of a pre-Klondikean weathering-induced oxidation event and challenge the traditional explanation of Broken Hill-type deposits as merely metamorphosed SEDEX deposits. Instead, we suggest that the massive sulfide deposits experienced a complex history, starting with initial SEDEX-type mineralization, followed by near-surface oxidation with spatial metal separation, and then sulfidation of this oxidized ore during medium- to high-grade metamorphism.
\end{abstract}

Keywords Metamorphic sulfidation $\cdot$ Sulfide inclusions $\cdot$ Base metal deposit $\cdot$ Aggeneys $\cdot$ Gamsberg

\section{Introduction}

The world-class Gamsberg $\mathrm{Zn}$ deposit is part of the Aggeneys-Gamsberg ore district, located c. $700 \mathrm{~km}$ north of Cape Town (South Africa). Due to its very high Zn tonnage

Editorial handling: C. Hauzenberger

Stefan Höhn

stefan.hoehn@uni-wuerzburg.de

1 Department of Geodynamics and Geomaterials Research, Institute of Geography and Geology, Bavarian Georesources Centre (BGC), University of Würzburg, Am Hubland, 97074 Würzburg, Germany

2 Department of Geological Sciences, University of Cape Town, Rondebosch 7701, South Africa

3 Vedanta Zinc International, Vedanta Resources Plc, 1 Penge Road, Aggeneys 8893, South Africa it is classified as giant, close to the group of the supergiant deposits (Large et al. 2002). Together with the Broken Hill, Black Mountain and Big Syncline deposits it forms one of the world's largest base metal anomalies (Fig. 1).

With resources of at least $214 \mathrm{Mt}$ at $6.73 \% \mathrm{Zn}, 0.5 \% \mathrm{~Pb}$ and $5 \mathrm{~g} / \mathrm{t} \mathrm{Ag}$, Gamsberg is the most $\mathrm{Zn}$-rich deposit within the ore district (Rozendaal et al. 2017) and the end member of a pronounced spatial metal zonation with $\mathrm{Cu}-\mathrm{Pb}$-rich deposits in the west (Broken Hill, Black Mountain) and the huge Gamsberg Zn deposit in the east. All deposits of the Aggeneys-Gamsberg ore district have been classified as Broken Hill-type (e.g. Spry and Teale 2021), generally thought to represent sedimentary exhalative (SEDEX) deposits that experienced amphibolite- to granulite-facies metamorphism (Sangster 2020 and references therein). However, a high mineralogical variability, the pronounced metal zonation and significant levels of base metals in non-sulfides (e.g. gahnite) cannot be explained easily by this genetic model. 


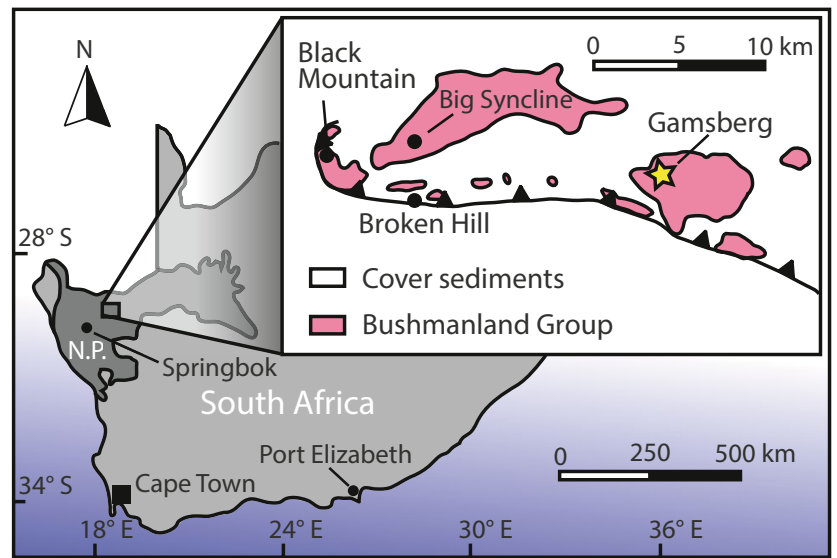

Fig. 1 Location of the Gamsberg deposit within the Aggeneys-Gamsberg ore district; N.P. - Namaqualand Province (after Stalder and Rozendaal 2004; McClung et al. 2007)

Furthermore, various geochemical anomalies in the immediate vicinity of the ore district (e.g., Willner et al. 1990) and several studies, which point to inconsistencies in the redox conditions of the deposits (e.g., Stalder and Rozendaal 2005b; Cawood and Rozendaal 2020), all suggest a more complicated metallogeny. An oxidation event affecting the whole ore district between the Okiepian (1210-1180 Ma) and Klondikean (1040-1020 Ma) orogenic events (Clifford et al. 2004) has been suggested based on $\mathrm{Cu}$ isotope data (Höhn et al. 2020). The current study concerns detailed mineral chemical analyses of hitherto unexplained textures of the sulfidic ore, which will be used to demonstrate the possibility of metamorphic sulfidation.

\section{Geological setting}

The Gamsberg deposit is located in the Namaqua Province, which constitutes the western part of the Mesoproterozoic Namaqua-Natal Province (e.g. Cornell et al. 2006). This province is divided into several subprovinces that bear characteristics similar to those of accretionary terranes at convergent margins (Colliston et al. 2017). Stratigraphically, the orebearing units are part of a volcano-sedimentary succession (Bushmanland Group), comprising biotite-sillimanite schist, paragneiss, quartzite, in places graphite-rich sillimanite-mica schist, and at the top of the group, especially in the vicinity of the stratiform ore bodies, meta-exhalites like iron formation. The protoliths of the Bushmanland Group predate the Namaquan collision at c. $1200 \mathrm{Ma}$ (Clifford et al. 2004), whereas the depositional age of the base metal-rich strata is constrained between $1285 \pm 14$ and $1198 \pm 10 \mathrm{Ma}$ (Cornell et al. 2009).

The Bushmanland Group is unconformably overlain by a volcano-sedimentary succession (Koeris Formation), starting with a basal meta-conglomerate and overlain by quartzite, para- and orthogneisses as well as amphibolite. The unconformity between the Bushmanland Group and the post-Okiepian Koeris Formation, located only a few meters above the ore-bearing stratigraphic level (Fig. 2; Ryan et al. 1986; Lipson 1990; Rozendaal et al. 2017), is a hiatus whose duration is poorly defined between $<1$ and 130 million years (Colliston et al. 2012). Over this time, the Bushmanland Group was affected by weathering, erosion and peneplanation. This opens up the possibility that the ore bodies situated below the unconformity, although sulfidic in nature, underwent a phase of oxidation as suggested by a recent $\mathrm{Cu}$ isotope study (Höhn et al. 2020). The protracted thermal history of the Bushmanland Group had two peaks that correspond to the Okiepian (1210-1180 Ma) and Klondikean (1040-1020 Ma) orogenic events (Clifford et al. 2004; Cornell et al. 2009). Granulite-facies peak-metamorphic conditions were reached at least in the Okiepian event (Bial et al. 2015), whereas the wider region around Aggeneys only experienced an upper amphibolite-facies overprint (Willner et al. 1990; Frimmel et al. 1995).

The ore-district comprises four major deposits (Fig. 1) with estimated resources of $385 \mathrm{Mt}$ ore with up to $6.73 \%$ $\mathrm{Zn}, 2.88 \% \mathrm{~Pb}, 0.5 \% \mathrm{Cu}$, and $34 \mathrm{ppm} \mathrm{Ag} \mathrm{(Rozendaal} \mathrm{et} \mathrm{al.}$ 2017). In places, "meta-exhalites" like iron formation, coticules, apatite-rich rocks and quartz-gahnite rocks are spatially associated with the ore (Fig. 2; McClung et al. 2007; Rozendaal et al. 2017).

The Gamsberg itself is a steep-sided inselberg at the eastern margin of the Aggeneys-Gamsberg ore district. It comprises a large sheath fold that plunges in northeasterly direction (Fig. 2b, c). In the ore district, the Bushmanland Group lacks an identifiable basement because of peakmetamorphic anataxis (Cornell et al. 2009). The oldest recognizable stratigraphic unit is the Wortel Formation. At its base, it consists of a quartz-biotite-sillimanite schist that crops out at the flanks of the inselberg and develops into a white quartzite at the highest elevations of the hill. The top of the Wortel Formation is a thin aluminous schist. The base of the Hotson Formation consists of a dark ferruginous quartzite with quartz pebble conglomerate and thin layers of aluminous schist (Rozendaal et al. 2017). The Gams Member at the top of the Hotson Formation comprises two similar psammo-pelitic schists at the base and the top with the ore zone between them (McClung et al. 2011, Rozendaal 1986). The Gams Member is located at the outer rim of the central depression within the Gamsberg. A major unconformity in the hanging wall separates the mineralized part of the Hotson Formation from the Koeris Formation. Metabasalt above the conglomerate, quartzite and mica schist of the Koeris Formation yielded a $\mathrm{U} / \mathrm{Pb}$ zircon age of $1130 \pm 35 \mathrm{Ma}$, which is younger 


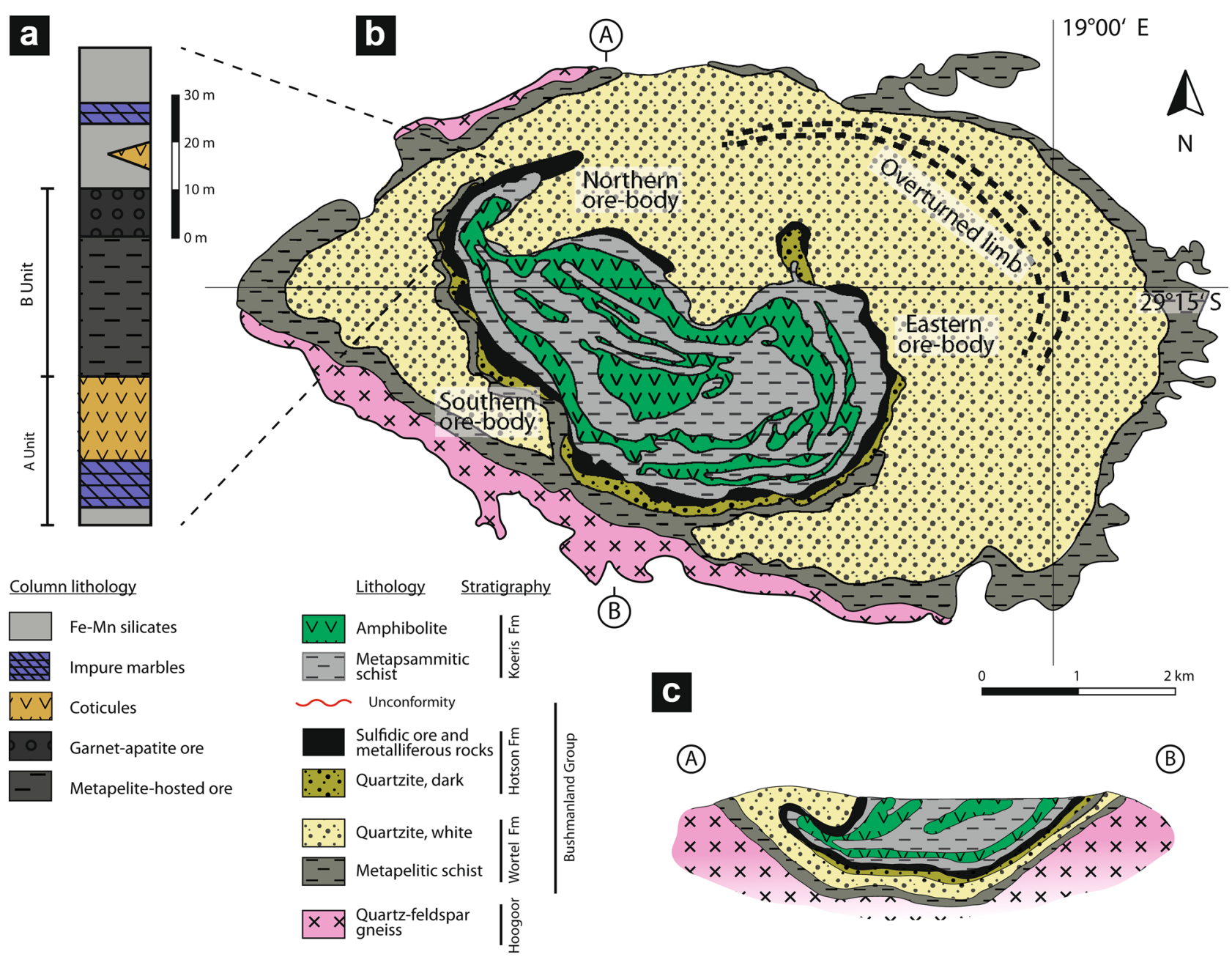

Fig. 2 a Lithological column through the mineralized part of the Hotson Formation in the northern orebody (after Rozendaal et al. 2017); b Geology of the Gamsberg deposit (after Stalder and

than the Okiepian collision event (Cornell et al. 2009). Therefore, the first pervasive deformation of the Koeris Formation rocks has been related to the Klondikean orogenic event. Surface exposure of the Koeris Formation is concentrated in the middle of the central depression of the Gamsberg. The stratigraphic position of the gneisses surrounding the inselberg is still a matter of debate. The Hoogoor Gneiss has been referred to as basement and source of the detritus for the metasedimentary succession of the Bushmanland Group. However, no zircon grains with typical Hoogoor age have been found so far in the succession in the hanging wall of the gneiss (Bailie et al. 2007). Furthermore, Cornell et al. (2009) investigated the Hoogoor Gneiss at the base of the Gamsberg and argued for an intrusive origin with an age of $1149 \pm 15 \mathrm{Ma}$. This would make the unit younger than the mineralized zone but older than the Koeris Formation.

Rozendaal 2004); c Cross-section of the Gamsberg deposit through the northern orebody (Stalder and Rozendaal 2004)

At the Gamsberg, the mineralized Hotson Formation can be subdivided into three units (Fig. 2a). The A unit consists of a thin garnet-pyroxene-amphibolite-magnetite rock at the base, several meters of impure marble and a fine-grained quartz-garnet-feldspar-clinopyroxene rock, which add up to a total thickness of 10 to $30 \mathrm{~m}$ (Stalder and Rozendaal 2004). The B unit consists predominantly of muscovite-sillimanite schist with disseminated sphalerite and galena and, at the northern and southern orebody, a garnet-apatite ore of minor thickness at the top (Rozendaal et al. 2017). Apatite nodules within the upper B unit have been suggested to represent a palaeo-redox boundary (Stalder and Rozendaal 2004). The $\mathrm{C}$ unit is heterogeneous and consists of several $\mathrm{Fe}-\mathrm{Mn}$-rich rocks. In the case of the northern orebody, which is essentially devoid of sulfides, these consist of Fe-Mn-silicates, Fe-oxides and minor carbonates. 


\section{Materials and methods}

\section{Sample collection}

Sample material comprised drill cores from four different locations in the northern orebody of the Gamsberg deposit (Fig. 3; Supplementary material 1). It was provided by Vedanta Resources in March 2019. All samples are garnetapatite ore from the upper part of the B unit.

\section{Thin section preparation and optical petrography}

Standard-sized $\sim 27 \times 47 \mathrm{~mm}$ thin sections of $25 \mu \mathrm{m}$ thickness were prepared from selected drill core portions following routine procedures, using bonded silicon-carbide papers to final fineness of 1200 mesh. Section surfaces were polished with diamond pastes on cloth to obtain a mirror finish.

The polished sections were examined using a Leica DM RXP petrographic microscope in plane- and cross-polarized, transmitted and reflected light. Locations suitable for determination of mineral chemistry were selected having immaculate surface finish, no visible solid or fluid inclusions or underlying wedges, and with well-defined mineral grain boundaries.

\section{Mineral chemistry by electron microprobe analysis (EMPA)}

After petrographic analysis, selected sulfide domains were analyzed for their chemical composition using a JEOL JXA $8800 \mathrm{~L}$ electron microprobe at the Institute of Geography and Geology, University of Würzburg. Polished section surfaces were coated with $\mathrm{a} \sim 20 \mathrm{~nm}$ carbon layer in a Leybold-Heraeus AS 050 device to minimize charging under the electron beam.

The emitted $\mathrm{K} \alpha$ and $\mathrm{L} \alpha \mathrm{X}$-rays were analyzed with four wavelength-dispersive spectrometers (WDS), equipped with TAP (As, Si), PET (Ag, Cd, S, Pb, Ni) and LIF (Fe, Cu, Co, $\mathrm{Zn}, \mathrm{Mn}$ ) crystals. The acceleration voltage for all measurements was $15 \mathrm{kV}$ with a beam current of $20 \mathrm{nA}$. The $\mathrm{M} \alpha$-Line was used for $\mathrm{Pb}$, the $\mathrm{L} \alpha$-line for $\mathrm{As}, \mathrm{Ag}$ and $\mathrm{Cd}$ and $\mathrm{K} \alpha$ for the other elements. For $\mathrm{As}, \mathrm{Ag}, \mathrm{Cd}, \mathrm{Pb}, \mathrm{Cu}, \mathrm{Ni}$ and $\mathrm{Zn}$, the measuring time was $30 \mathrm{~s}$ on the peak and $15 \mathrm{~s}$ on background positions before and after the peak. For Fe, $\mathrm{Si}, \mathrm{Co}$ it was $20 \mathrm{~s}$ on the peak and $10 \mathrm{~s}$ for the background. For $\mathrm{S}$ it was $30 \mathrm{~s}$ to $20 \mathrm{~s}$ and for $\mathrm{Mn} 40 \mathrm{~s}$ to $20 \mathrm{~s}$. The beam parameters for the compositional maps of garnet were $15 \mathrm{kV}, 20 \mathrm{nA}$ and a spot size of $1 \mu \mathrm{m}$.

$\mathrm{Si}$ was included in the analysis of the smallest sulfide inclusions $(<5 \mu \mathrm{m})$ in garnet to determine any $\mathrm{X}$-ray influences from the garnet host. Only results with $\mathrm{Si}$ content of $<0.07 \mathrm{wt} \%$ were considered in the further interpretation of the data. For all elements, the Cameca standard-set SX GEO STDS 1987 was used for calibration. Raw element data were ZAF corrected (Z: Philibert-Tixier (1968); A: Philibert (1963); F: Reed 1965) and corrected element contents in silicate minerals were converted to weight percentage oxides assuming stoichiometry. $\mathrm{FeO}^{\mathrm{T}}$ represents total iron (oxide) content. Oxide contents were recast into mineral composition formulae in atoms per formula unit (apfu) using the application by Locock (2008) for garnets. Analyses of pyrite and/or sphalerite were recast into apfu on the basis of a fixed number of sulfide atoms.

The lower limits of detection (LLD) were generally better than $0.05 \mathrm{wt} \%$, and are specified in a separate column together with the data. Selected data are collated in
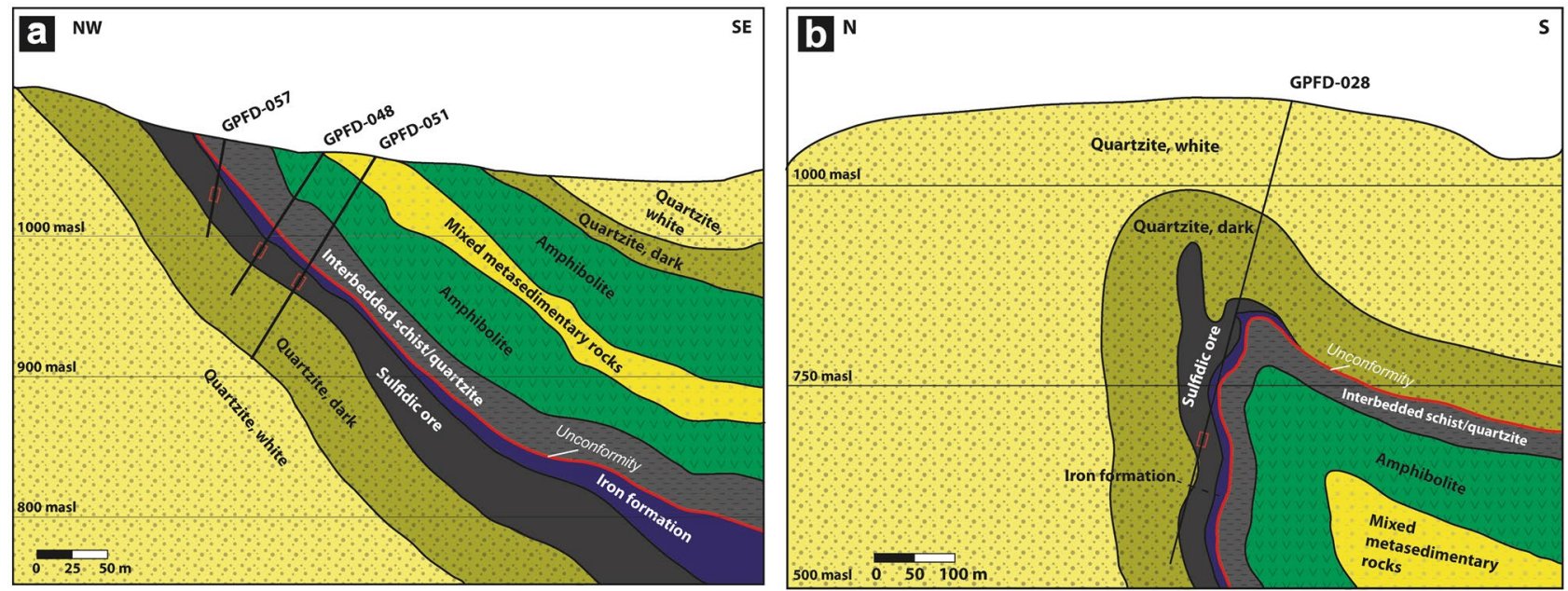

Fig. 3 Sections through the northern ore-body of the Gamsberg deposit with the bore holes GPFD048, GPFD051, GPFD57 and b GPFD028. Sampled core is marked with red boxes 
Tables 1-5; additional data are reported in the Supplementary Electronic Materials 2-7. Mineral abbreviations are as suggested by Whitney and Evans (2010). The processing of analyses was performed using Microsoft Excel and the GCDkit4.1 (Janoušek et al. 2006).

\section{Results}

\section{Garnet}

A total of ninetysix analyses were conducted on various areas of seventeen garnet grains, which showed a distinct zonation in their back-scatter electron images with a patchy/streaky rim with large sulfide inclusions $(>25 \mu \mathrm{m})$. All revealed a relatively uniform core zone with smaller $(<15 \mu \mathrm{m})$ sulfide inclusions (Fig. 4a, b). The contact between both zones is relatively sharp, irregular and does not show any shapes typical of crystal overgrowth (Fig. 4c, d).

The garnet is mainly spessartine but some compositional zonation was noted between cores and rims (Table 1). The former have a compositional range of $\mathrm{Sps}_{86.2-89.4} \mathrm{Alm}_{1.1-8.0} \mathrm{Gro}_{0.5-3.0} \mathrm{Pyr}_{1.3-2.4}$. The calculated $\mathrm{Fe}^{3+}$ content on average was $1.93 \mathrm{wt} \%$ within the cores (Supplementary electronic material 2). The patchy/ streaky rim areas are somewhat more $\mathrm{Fe}^{3+}$-rich giving rise to a distinct minor andradite component with
$\mathrm{Sps}_{86.2-90.7} \mathrm{Alm}_{0.1-7.2} \mathrm{Pyr}_{0.5-2.9} \mathrm{And}_{0.0-3.6}$. The lower $\mathrm{Al}$ contents are in agreement with more $\mathrm{Fe}^{3+}$ in the octahedral sites $(\varnothing=3.3 \mathrm{wt} \%)$.

\section{Sulfides}

A total of 711 analyses were conducted on sulfides from the garnet-apatite ore (upper B Unit). With few exceptions $\mathrm{Co}, \mathrm{Ni}, \mathrm{Cu}, \mathrm{As}, \mathrm{Ag}$ and $\mathrm{Pb}$ were below the detection limit in sphalerite and $\mathrm{Pb}, \mathrm{Ni}, \mathrm{Cu}, \mathrm{Ag}, \mathrm{Cd}$ and $\mathrm{Mn}$ values were below the detection limit in pyrite.

\section{Sulfide inclusions in garnet}

Sulfide inclusions are ubiquitous in garnet grains of the ore. Nevertheless, garnet grains revealing a pronounced zonation with an inner core and a rim zone and both hosting sulfide inclusions (e.g. Fig. 4) are quite rare. Altogether 191 analyses were performed on such sulfide inclusions (Table 2; Supplementary electronic material 3). Because of the $\mathrm{Zn}$ - and Fe-rich nature of the deposit, the sulfide inclusions are generally dominated by sphalerite and subordinate pyrite. Galena is rare.

A total of 162 analyses were performed on sphalerite inclusions in zoned garnet grains. In general, the sphalerite

Table 1 Typical compositions of garnet from borehole GPFD-028 of the Gamsberg deposit (wt\%)

\begin{tabular}{|c|c|c|c|c|c|c|c|c|c|}
\hline Measurment & LLD-value & Gams02G9 & Gams02G12 & Gams02G17 & Gams02G31 & Gams02G45 & Gams02G46 & Gams02G57 & Gams02G60 \\
\hline Position & $(\mathrm{ppm})$ & Core & Core & Core & Core & Rim & Rim & Rim & Rim \\
\hline $\mathrm{SiO}_{2}$ & $<108$ & 35.50 & 35.39 & 35.33 & 35.69 & 34.96 & 35.33 & 35.23 & 36.00 \\
\hline $\mathrm{TiO}_{2}$ & $<174$ & b.d. & b.d. & 0.06 & 0.07 & b.d. & b.d. & b.d. & b.d. \\
\hline $\mathrm{Al}_{2} \mathrm{O}_{3}$ & $<86$ & 21.40 & 21.20 & 21.30 & 21.26 & 20.10 & 20.16 & 19.53 & 19.98 \\
\hline $\mathrm{Cr}_{2} \mathrm{O}_{3}$ & $<265$ & 0.06 & b.d. & b.d. & b.d. & b.d. & b.d. & b.d. & 0.08 \\
\hline $\mathrm{FeO}$ & $<267$ & 3.53 & 4.45 & 3.47 & 4.68 & 5.37 & 5.26 & 5.78 & 4.92 \\
\hline $\mathrm{MnO}$ & $<203$ & 38.02 & 37.87 & 38.40 & 37.44 & 37.67 & 37.49 & 38.63 & 38.49 \\
\hline $\mathrm{MgO}$ & $<72$ & 0.56 & 0.41 & 0.58 & 0.39 & 0.49 & 0.53 & 0.46 & 0.47 \\
\hline $\mathrm{CaO}$ & $<98$ & 1.14 & 0.57 & 1.00 & 0.68 & 1.26 & 1.28 & 0.31 & 0.08 \\
\hline Total & & 100.25 & 99.94 & 100.18 & 100.20 & 99.90 & 100.09 & 99.98 & 100.03 \\
\hline \multicolumn{10}{|c|}{ End-member $(\mathrm{mol} \%)$} \\
\hline \multicolumn{2}{|l|}{ Spessartine } & 87.62 & 87.78 & 88.62 & 86.52 & 87.57 & 86.91 & 90.09 & 89.51 \\
\hline \multicolumn{2}{|l|}{ Almandine } & 3.46 & 5.78 & 2.48 & 7.42 & 1.85 & 3.52 & and & 3.86 \\
\hline \multicolumn{2}{|l|}{ Pyrope } & 2.28 & 1.68 & 2.36 & 1.6 & 2.01 & 2.15 & 0.47 & 1.87 \\
\hline \multicolumn{2}{|l|}{ Grossular } & 2.98 & 1.48 & 2.63 & 1.77 & & & & \\
\hline \multicolumn{2}{|l|}{ Uvarovite } & 0.19 & 0.09 & 0.12 & & & & & 0.2 \\
\hline \multicolumn{2}{|l|}{ Andradite } & & & & & 3.56 & 3.63 & 0.81 & \\
\hline \multicolumn{2}{|l|}{ Skiagite } & & & & & 0.9 & 0.44 & 4.17 & 3.32 \\
\hline \multicolumn{10}{|c|}{ Recalculated (wt\%) } \\
\hline \multicolumn{2}{|l|}{$\mathrm{Fe}^{2+}$} & 1.52 & 2.53 & 1.09 & 3.25 & 1.20 & 1.73 & 1.81 & 3.13 \\
\hline \multicolumn{2}{|l|}{$\mathrm{Fe}^{3+}$} & 2.24 & 2.13 & 2.65 & 1.58 & 4.64 & 3.92 & 4.41 & 1.99 \\
\hline
\end{tabular}


Fig. 4 a Transmission light photomicrograph of a zoned garnet grain and its different types of sulfide inclusions from the garnet-apatite ore of the Gamsberg deposit; $\mathbf{b}$ detail from a; c Backscatter electron image of a zoned garnet grain with sulfide inclusions; $\mathbf{d}$ relative iron distribution within the marked area of the grain. Grt=garnet, $\mathrm{Py}=$ pyrite, $\mathrm{Sp}=$ sphalerite
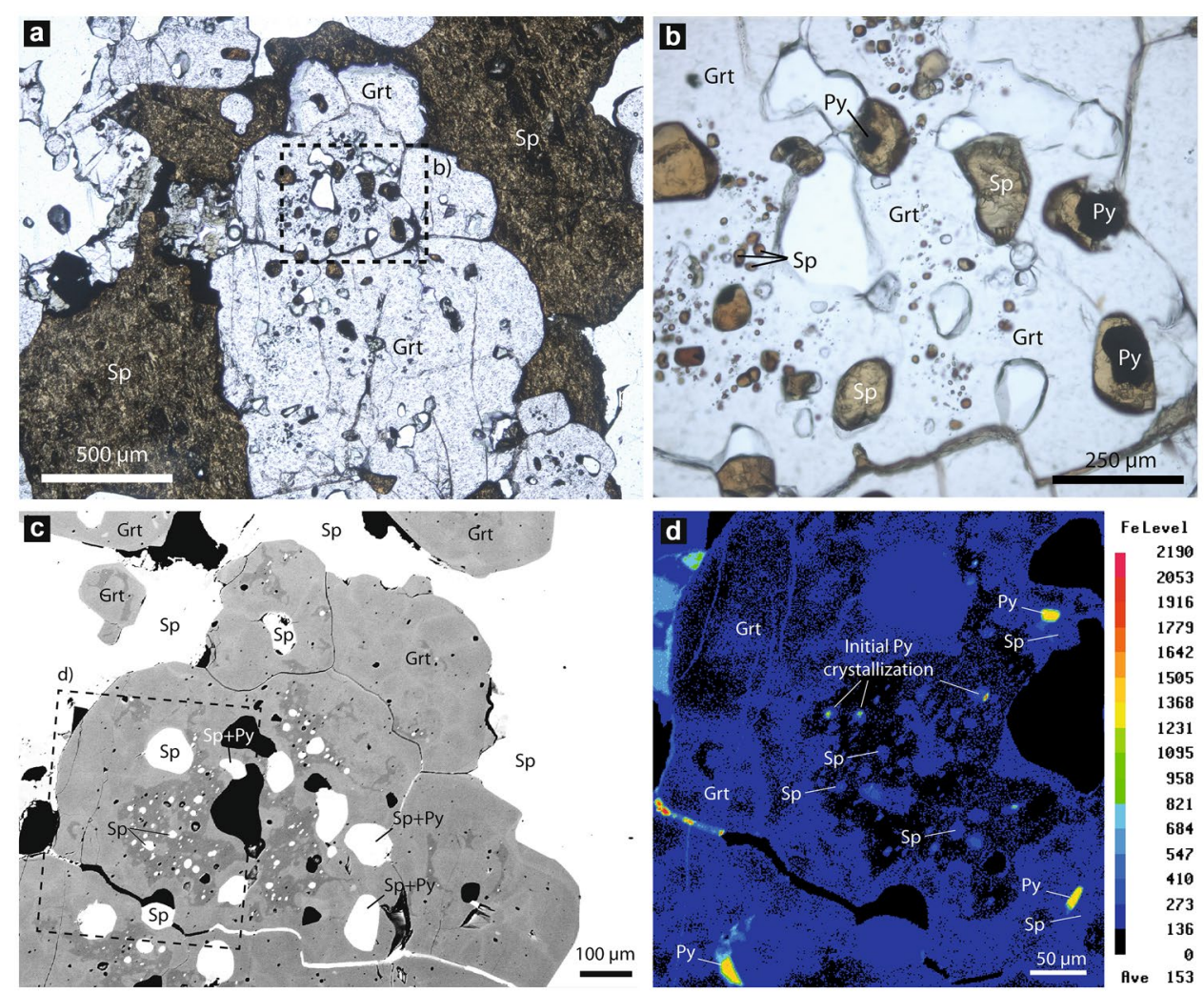

inclusions are rich in $\mathrm{Zn}(\varnothing=57.94 \mathrm{wt} \% ; \sigma=2.92)$ and $\mathrm{Mn}$ $(\varnothing=2.11 \mathrm{wt} \% ; \sigma=1.00)$ but relatively poor in $\mathrm{Fe}(\varnothing=6.18$ $\mathrm{wt} \% ; \sigma=1.87)$. With an average of $0.07 \mathrm{wt} \% \mathrm{Cd}$ is very low (Supplementary material 3).
In comparison to the average sphalerite composition, the small sphalerite inclusions $(<15 \mu \mathrm{m})$ from the $\mathrm{Fe}$ poor core zones $(\mathrm{Sp}-\mathrm{C})$ of the garnet grains are rich in $\mathrm{Fe}$ $(\varnothing=7.64 \mathrm{wt} \% ; \sigma=1.19 ; \mathrm{n}=67)$ and $\mathrm{Mn}(\varnothing=3.00 \mathrm{wt} \%$;

Table 2 Typical compositions of sphalerite from sulfide inclusions in garnet of the Gamsberg deposit (wt\%)

\begin{tabular}{llllllllll}
\hline Measurement & LLD-values & K1P2Sp186 & K1Sp597 & K1Sp604 & K1Sp620 & K1Sp606 & K1Sp608 & K1P1Sp129j & K1P1Sp30j \\
\hline Position & (ppm) & Core & Core & Core & Core & Rim & Rim & Rim & Rim \\
$\mathrm{Zn}$ & $<411$ & 56.58 & 54.46 & 55.34 & 54.19 & 60.20 & 59.92 & 61.64 & 61.10 \\
$\mathrm{Fe}$ & $<270$ & 7.95 & 8.19 & 7.93 & 8.00 & 4.49 & 4.28 & 3.91 & 4.35 \\
$\mathrm{~S}$ & $<112$ & 33.09 & 33.23 & 33.68 & 33.82 & 33.00 & 33.37 & 33.05 & 33.01 \\
$\mathrm{Mn}$ & $<179$ & 2.25 & 3.53 & 2.79 & 3.46 & 2.06 & 2.24 & 1.10 & 1.41 \\
$\mathrm{Co}$ & $<249$ & b.d. & b.d. & 0.05 & b.d. & b.d. & b.d. & b.d. & b.d. \\
$\mathrm{Ni}$ & $<226$ & b.d & b.d. & b.d.. & b.d. & b.d. & b.d. & b.d. & b.d. \\
$\mathrm{Cu}$ & $<273$ & b.d. & 0.05 & 0.06 & 0.06 & 0.07 & b.d. & b.d. & b.d. \\
$\mathrm{As}$ & $<414$ & b.d. & b.d. & b.d. & b.d. & b.d. & b.d. & b.d. & 0.12 \\
$\mathrm{Ag}$ & $<277$ & b.d. & b.d.. & b.d. & b.d. & b.d. & 0.06 & b.d. & b.d. \\
$\mathrm{Cd}$ & $<321$ & 0.09 & 0.07 & b.d. & b.d. & 0.06 & b.d. & 0.10 & b.d. \\
$\mathrm{Pb}$ & $<405$ & b.d. & b.d. & b.d. & b.d. & b.d. & b.d. & b.d. & b.d. \\
$\mathrm{Si}$ & $<54$ & b.d. & b.d. & 0.06 & b.d. & b.d. & b.d. & b.d. & b.d. \\
Total & & 100.05 & 99.62 & 99.91 & 99.64 & 99.95 & 99.95 & 99.82 & 100.05 \\
Atoms per formular unit (apfu) & & & & & & & & \\
$\mathrm{Zn}$ & & 0.82 & 0.80 & 0.81 & 0.80 & 0.89 & 0.89 & 0.91 & \\
$\mathrm{Fe}$ & 0.14 & 0.14 & 0.14 & 0.14 & 0.08 & 0.07 & 0.07 & 0.90 \\
$\mathrm{Mn}$ & 0.04 & 0.06 & 0.05 & 0.06 & 0.04 & 0.04 & 0.02 & 0.07 \\
\hline
\end{tabular}

$b d$ below lower limit of detection, $L L D$ Lower limit of detection 
$\sigma=0.87)$ and correspondingly depleted in $\mathrm{Zn}(\varnothing=55.26$ $\mathrm{wt} \% ; \sigma=2.00)$. The Cd content is the same $(0.07 \mathrm{wt} \%)$.

Compared to sphalerite from the garnet cores (Sp-C), sphalerite from larger inclusions $(>25 \mu \mathrm{m})$ from the Fe-rich rim zones (Sp-R) of the garnet grains is significantly lower in $\mathrm{Fe}(\varnothing=5.14 \mathrm{wt} \% ; \sigma=1.34 ; \mathrm{n}=95)$ and $\mathrm{Mn}$ $(\varnothing=1.49 \mathrm{wt} \% ; \sigma=0.46)$ and the Zn contents correspondingly higher $(\varnothing=59.83 \mathrm{wt} \% ; \sigma=1.75)$. With regard to the trace elements, there are no significant differences to Sp-C. Again, the Cd content is on average at $0.07 \mathrm{wt} \%$.

Sphalerite from outside the garnet grains $(\mathrm{Sp}-\mathrm{H})$ revealed the lowest $\mathrm{Fe}(\varnothing=2.78 \mathrm{wt} \% ; \sigma=0.73 ; \mathrm{n}=40)$ and $\mathrm{Mn}(\varnothing=0.48 \mathrm{wt} \% ; \sigma=0.20)$ contents of all investigated sphalerite types, which is in good agreement with its honey-yellow color. The $\mathrm{Cd}$ concentrations ( $\varnothing=0.08 \mathrm{wt} \%$; $\sigma=0.03$ ) are very similar to those in both sphalerite types in the interior of garnet grains.

The comparison between the three sphalerite types shows a distinct trend from the core of garnet grains (Sp-C), over the rims $(\mathrm{Sp}-\mathrm{R})$ to texturally late honey-yellow sphalerite $(\mathrm{Sp}-\mathrm{H})$. A decrease in $\mathrm{Fe}$ and $\mathrm{Mn}$ contents from the core to the exterior is matched by an increase in $\mathrm{Zn}$ as predicted by the mineral's stoichiometry (Fig. 5a, b). Even though some trace elements like $\mathrm{Cd}$ and $\mathrm{Co}$ reach detectable contents, no systematic relationship with $\mathrm{Zn}$ is noted (Fig. 5c, d).
Pyrite inclusions larger than $1 \mu \mathrm{m}$ were observed only in Fe-rich rim zones of the garnet grains. Smaller Fe-sulfides within sulfide inclusions from the core zones are only visible in compositional maps.

A total of twentynine analyses were performed on pyrite from sulfide inclusions in Fe-rich garnet rims. In general, this pyrite is very poor in trace elements but rich in $\mathrm{Mn}$ $(\varnothing=0.40 \mathrm{wt} \% ; \sigma=0.17)$. With an average of $0.53 \mathrm{wt} \%$ and a standard deviation of 0.40 , the $\mathrm{Zn}$ distribution is heterogeneous. Arsenic concentrations are low with an average of $0.34 \mathrm{wt} \%(\sigma=0.69)$.

\section{Graphic-textured sulfide aggregates}

A prominent textural feature of the Gamsberg ore are fine graphic-like intergrowths of pyrite and sphalerite, which show droplet- and bulge-shaped phase boundaries (Fig. 6). These sulfide aggregates are enriched in pyrite compared to their local surroundings.

Seventynine chemical analyses were performed on sphalerite from seven graphic-textured sulfide aggregates (Table 3; Supplementary electronic material 3). No significant differences could be found between the sulfide aggregates but all of them share a characteristic chemical signature. Sphalerite in these aggregates is generally very poor
Fig. 5 Various element ratios of sphalerite in and around garnet grains from the Gamsberg deposit. $\mathrm{Sp}-\mathrm{C}=$ sphalerite from garnet core areas, $\mathrm{Sp}-\mathrm{R}=$ sphalerite from garnet rims,

$\mathrm{Sp}-\mathrm{H}=$ texturally late sphalerite around garnet grains. Position of the drill cores GPFD051 and GPFD057 indicated in Supplementary material 1
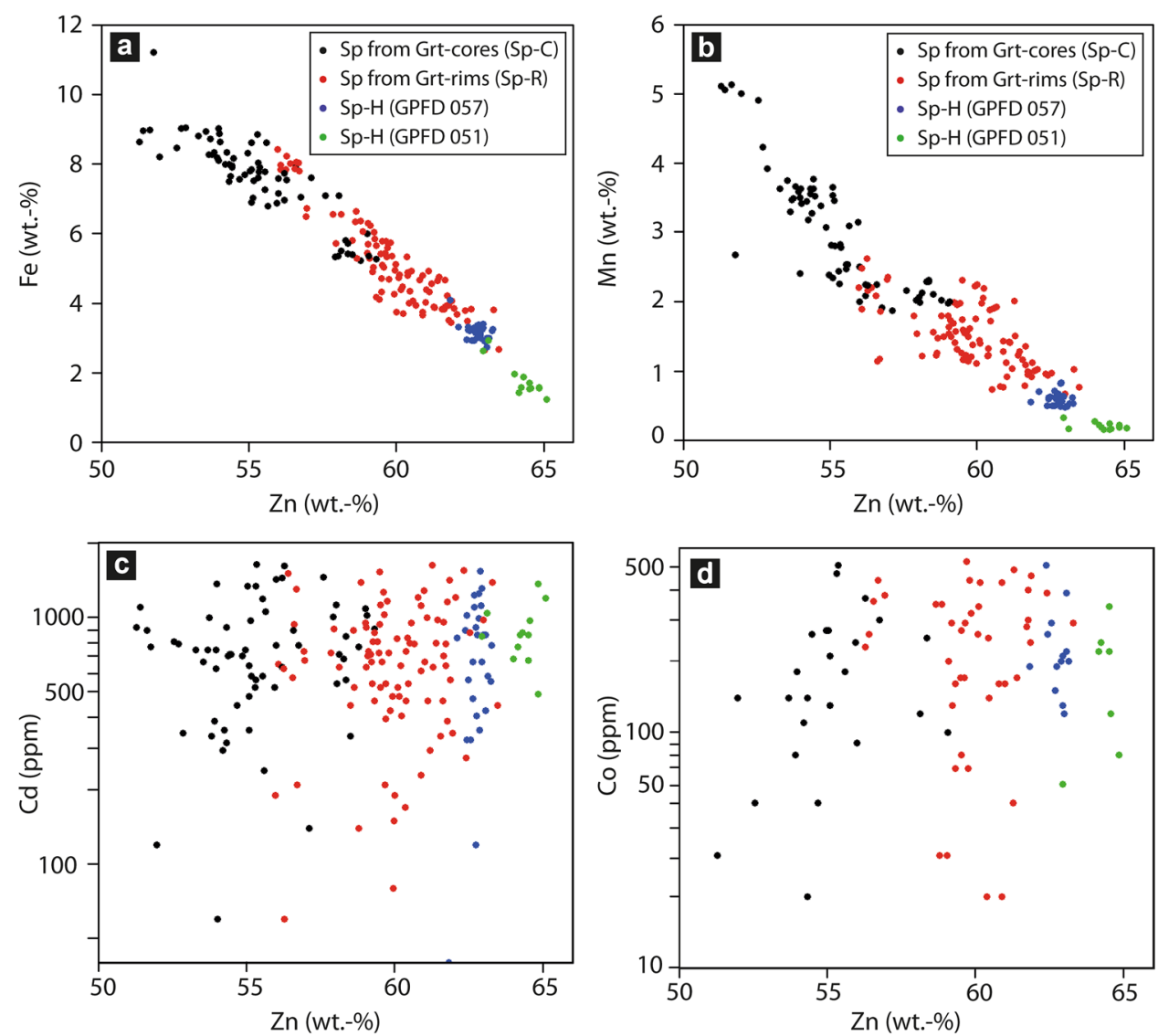
Fig. 6 a and $\mathbf{b}$ Graphic-textured sulfide aggregates with pervasive droplet- and bulge-shaped phase boundaries; c and d Graphic-textured sulfides replacing pyrrhotite and magnetite. Garnet-apatite ore from drill core GPFD048 (Gamsberg deposit). Ap=apatite, Grt = garnet, $\mathrm{Mag}=$ magnetite, $\mathrm{Po}=$ pyrrhotite, $\mathrm{Py}=$ pyrite, $\mathrm{Qz}=$ quartz, $\mathrm{Sp}=$ sphalerite
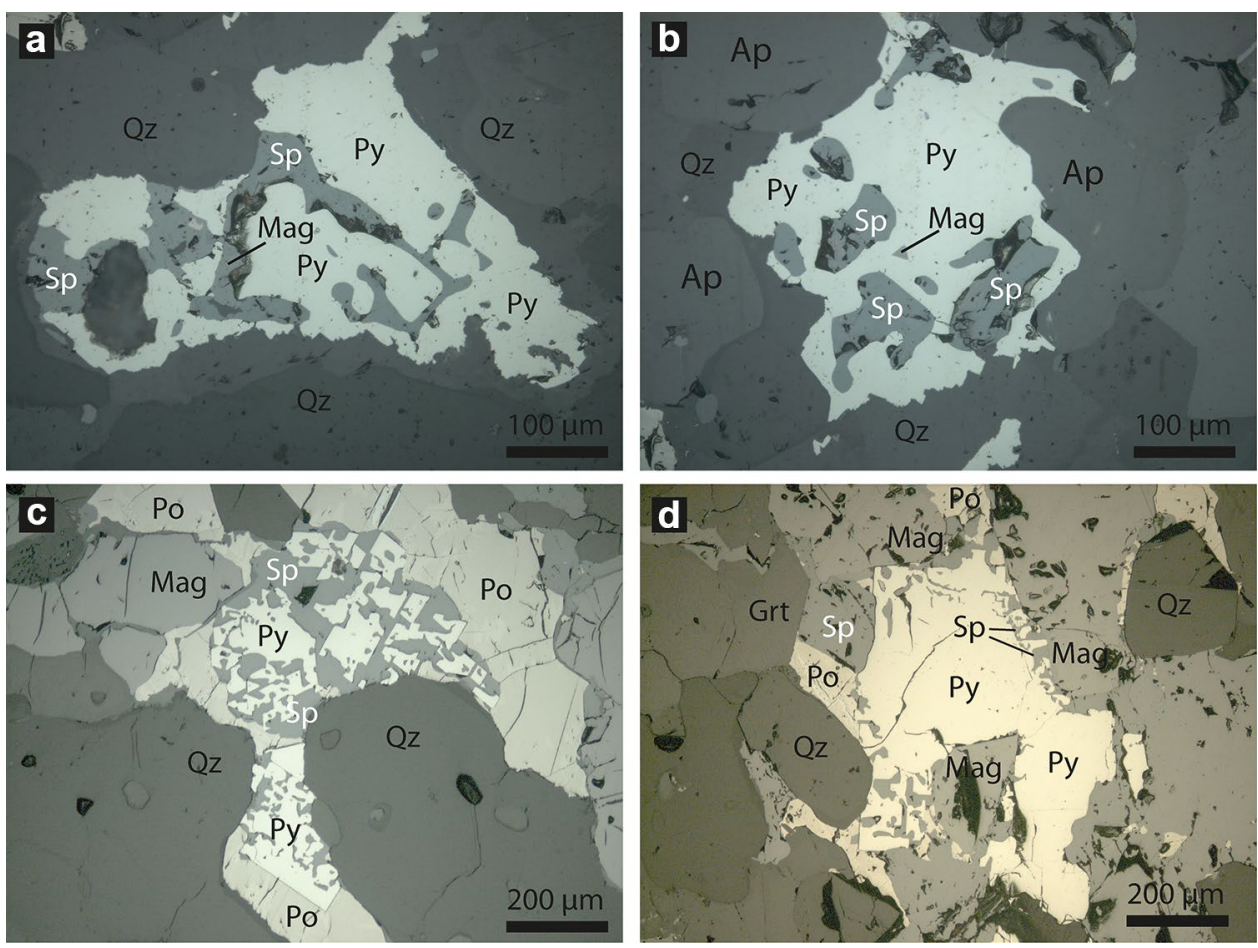

in $\mathrm{Mn}(\varnothing=0.65 \mathrm{wt} \% ; \sigma=0.18)$ but rich in $\mathrm{Fe}(\varnothing=8.90 \mathrm{wt} \%$; $\sigma=0.61)$ and $\mathrm{Cd}(\varnothing=0.11 \mathrm{wt} \% ; \sigma=0.05)$.

The sixtysix chemical analyses on pyrite (Table 3; Supplementary electronic material 4) closely intergrown with sphalerite reveal no significant differences between the graphic-textured sulfide aggregates. A characteristic feature is their relatively $\mathrm{Zn}$-rich nature $(\varnothing=0.21 \mathrm{wt} \%)$ with a very heterogeneous distribution $(\sigma=0.22)$. Its Mn content is with $0.04 \mathrm{wt} \%$ lower than in the closely associated sphalerite.

In spite of their close spatial association, the concentrations of $\mathrm{Zn}$ and $\mathrm{Fe}$ in pyrite and sphalerite are uniform with sharp contact zones and without any internal zonation in the grains (Fig. 7c, d). Grain boundaries between magnetite/ pyrrhotite and the sulfide aggregates mostly reveal irregular shapes indicative of chemical disequilibrium (Fig. 6b, magnetite grain in the center). Small Al-rich veins are a common feature associated with these disequilibrium textures and point at the presence of minute Al-silicates (Fig. 7b).

\section{Replacement of pyrrhotite by pyrite along micro-fractures}

A completely different feature of the Gamsberg deposit is the replacement of pyrrhotite by pyrite along microfractures (Fig. 8). Element mapping revealed a progressive decrease in Fe content from a given micro-fracture into the surrounding pyrrhotite grain (Fig. 8c), which correlates with a corresponding increase in $\mathrm{S}$ (Fig. 8d). Compared to the graphic-textured sulfide, this transition is rather smooth. Quartz is located as open space filling within the main micro-fractures but the Si-abundance map shows elevated $\mathrm{Si}$-contents in the whole area affected by sulfidation. Noticeable is the absence of Si within the high-S pyrite areas and its spatial concentration between the two sulfide phases (Fig. 8b). Whereas it is obvious that those chemical and mineralogical features are related to brittle deformation, they are typically cut by one or more fracture generations, which show no signs of sulfidation. In places where fracture-related sulfidation and graphic-textured sulfides intersect, the latter cut across the former.

\section{Phyllic alteration}

In some volumetrically subordinate domains of the garnet-apatite ore, a strong phyllic alteration is noted. In contrast to all adjacent core material, these zones nearly exclusively consist of medium to fine-grained muscovite, quartz and chlorite (GPFD051; Fig. 9). The most prominent features of these phyllic alteration zones are sulfide-rich veins, spatially associated with coarsegrained quartz $(>250 \mu \mathrm{m})$, muscovite and chlorite. The sulfides comprise nearly equal amounts of sphalerite, pyrite and pyrrhotite. The areas around the veins show an alternation of layers of medium-grained quartz (up to $100 \mu \mathrm{m}$ in size), sphalerite, pyrite, pyrrhotite and minor sericite with layers of fine-grained quartz, sericite and sphalerite. Fe-sulfides are mostly absent in the 


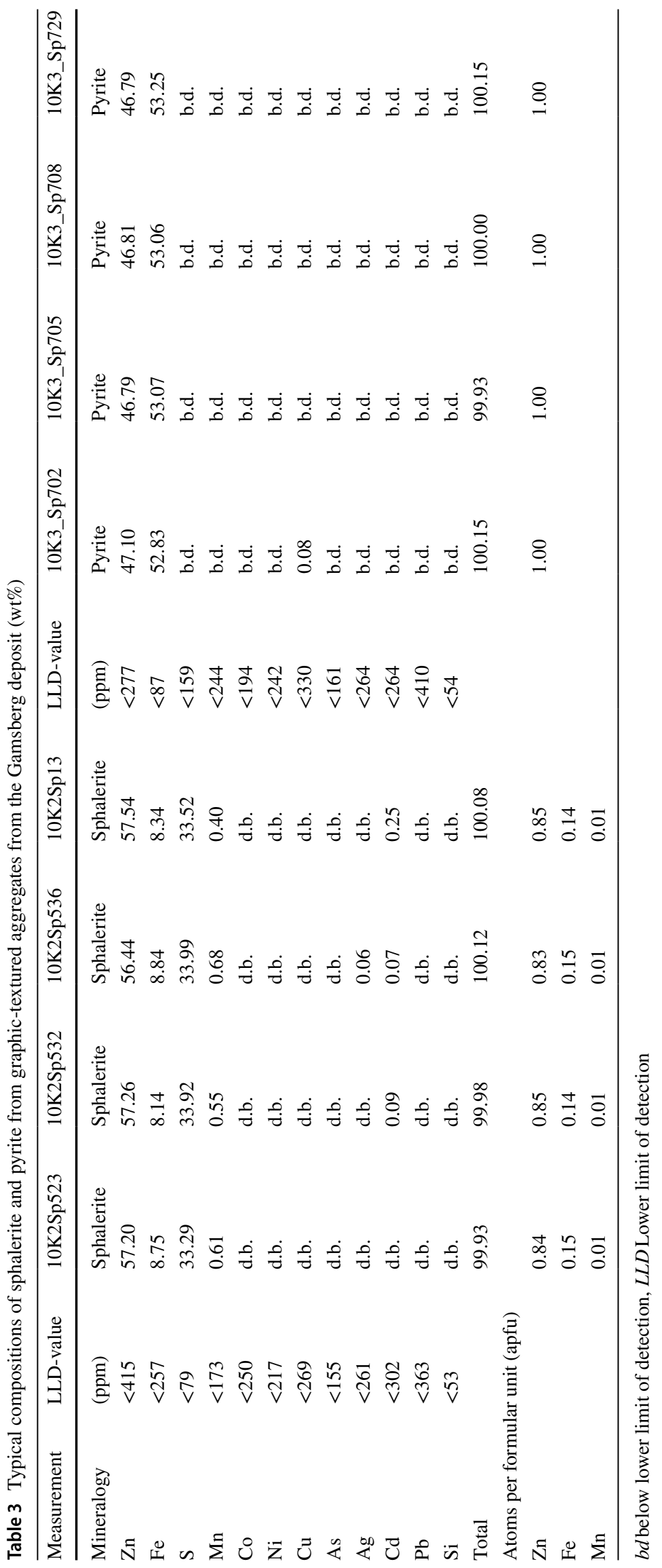


Fig. 7 a Reflected light image of graphic-textured sulfides at the boundaries between pyrite, sphalerite and magnetite; $\mathbf{b}, \mathbf{c}$, d relative element abundance map of $\mathrm{Al}, \mathrm{Fe}$ and $\mathrm{Zn}$. Garnetapatite ore from drill core GPFD 048 (Gamsberg deposit) Mag $=$ magnetite, $\mathrm{Po}=$ pyrrhotite, $\mathrm{Py}=$ pyrite, $\mathrm{Qz}=$ quartz, $\mathrm{Sp}=$ sphalerite
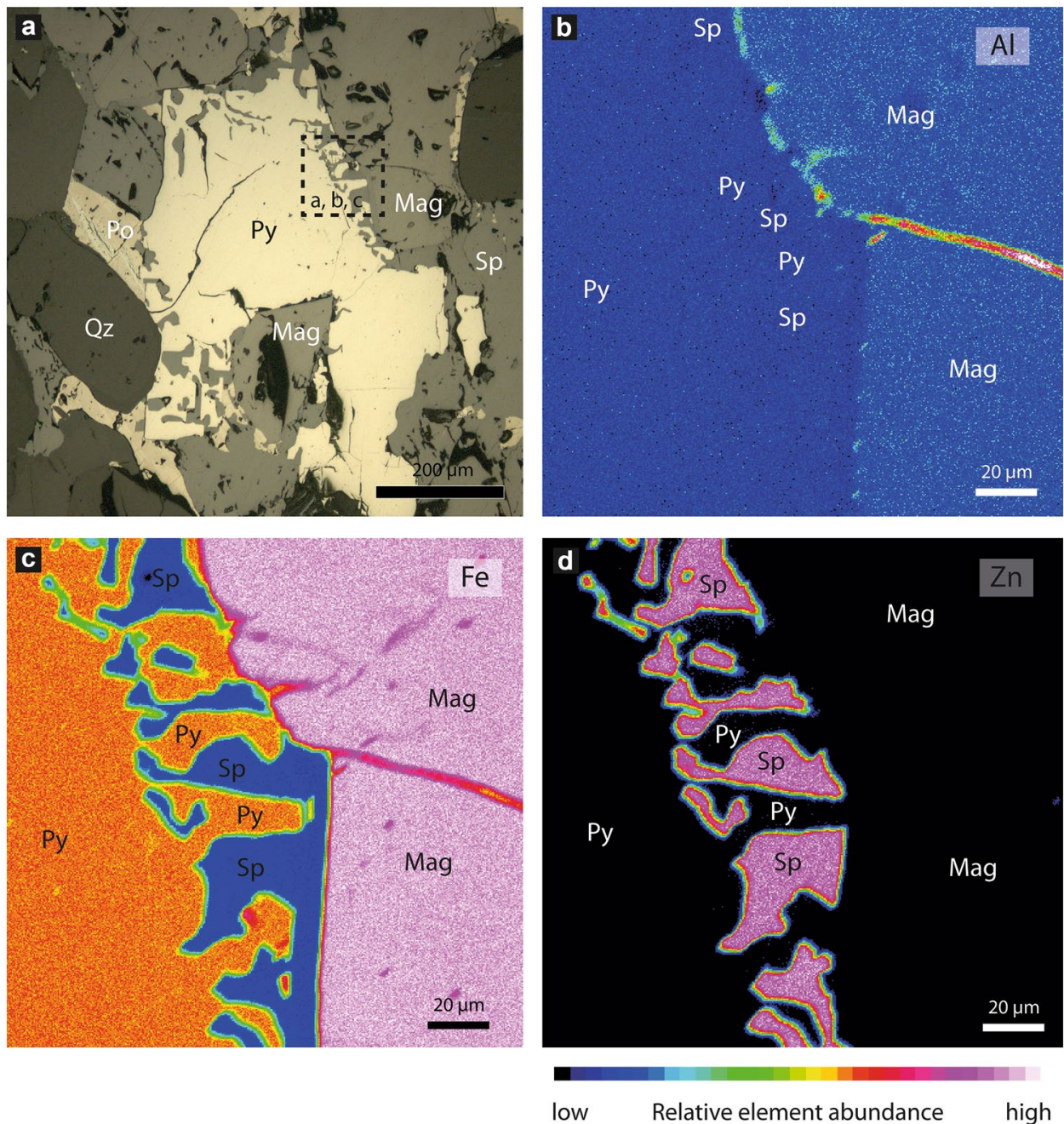

fine-grained $(<70 \mu \mathrm{m})$ domains but present in mediumto coarse-grained layers and domains.

\section{Sulfide veins}

Coarse-grained veins of massive sulfide are spatially associated with chlorite and muscovite (Fig. 9a, b). Fifty chemical analyses were performed on sphalerite from the veins and their immediate surroundings ( $\mathrm{Sp}-\mathrm{cg}$; Table 4; Supplementary electronic material 5). Fe $(\varnothing=9.51 \mathrm{wt} \%$; $\sigma=0.58)$. The Mn contents $(\varnothing=5.13 \mathrm{wt} \% ; \sigma=0.40)$ vary widely and correlate with those in nearby silicate minerals. Thus, sphalerite with the highest $\mathrm{Zn}$ and correspondingly lowest $\mathrm{Fe}$ - and $\mathrm{Mn}$ contents occurs next to $\mathrm{Fe}$ - and Mn-rich chlorite (Fig. 10). The associated pyrite is low in trace elements, except for As with $\varnothing=0.18 \mathrm{wt} \%(\sigma=0.16$, $\mathrm{n}=26)$. The mean values of Co $(0.07 \mathrm{wt} \%)$ and $\mathrm{Zn}(0.06$ $\mathrm{wt} \%)$ are above the detection limit but with high standard deviations of 0.06 and 0.08 .

\section{Sulfides in medium-grained domains}

Sulfides in medium-grained domains comprise predominantly sphalerite but also pyrite and pyrrhotite both of which are absent in the fine-grained domains. Prominent is the abundance of inclusions in quartz within the coarsegrained domains. We conducted thirtynine analyses on thirty medium-sized $(>100 \mu \mathrm{m})$ sphalerite grains $(\mathrm{Sp}-\mathrm{mg})$ (Table 5; Supplementary electronic material 6). With an average Fe content of $9.20 \pm 0.37 \mathrm{wt} \%$ and a Mn content of $4.98 \pm 0.33$ ) these coarse sphalerite grains are slightly depleted in these elements compared to sphalerite in the veins (Fig. 9a, b), although the concentrations overlap within error. The $\mathrm{Cd}$ concentration in sphalerite is with $0.11 \mathrm{wt} \%$ among the highest of the deposit. Pyrite from the mediumgrained domains (Supplementary material 6) revealed a chemistry very similar to pyrite from the veins themselves. Only the As contents are, on average, slightly lower $(\varnothing=0.12$ $\mathrm{wt} \%)$, whereas those of $\mathrm{Zn}$ vary strongly $(\sigma=0.11 \mathrm{wt} \%)$ on a negligibly higher level $(\varnothing=0.25 \mathrm{wt} \%)$. 
Fig. 8 a Reflected light image of sulfidation of pyrrhotite to pyrite along micro-fractures and relative element abundance maps showing $\mathbf{b}$ silicon, $\mathbf{c}$ iron and d sulfur; Garnet-apatite ore from drill core GPFD048 (Gamsberg deposit). Po = Pyrrhotite, $\mathrm{Py}=$ Pyrite, $\mathrm{Qz}=$ quartz, $\mathrm{Sp}=$ sphalerite
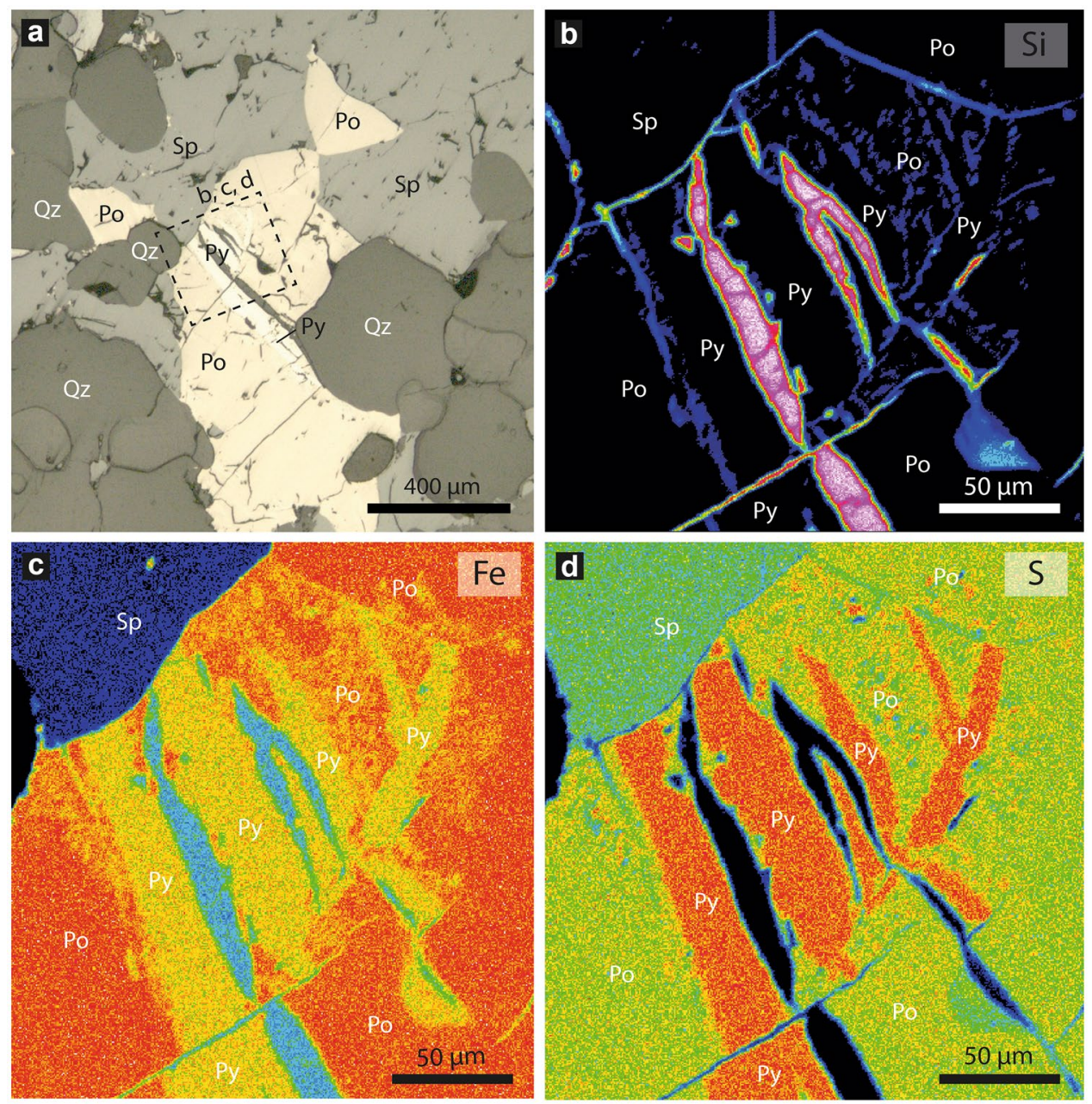

Low

Relative element abundance

High

\section{Sulfides in fine-grained domains}

In the finest grained areas of the deposit, sulfides, predominantly sphalerite $(<30 \mu \mathrm{m}$ in size), appear as pore-fillings between quartz and muscovite. Sixtynine analyses were performed on fortythree sphalerite grains (Sp-fg; Table 5; Supplementary electronic material7). Among sphalerite within the phyllic alteration zone, the finest grained sphalerite is poorest in $\mathrm{Fe}(\varnothing=8.92 \mathrm{wt} \% ; \sigma=0.19)$ and $\mathrm{Mn}(\varnothing=4.90 \mathrm{wt} \%$; $\sigma=0.15)$. The Cd values $0.12 \mathrm{wt} \%(\sigma=0.04)$ are similar to those of sphalerite from the coarser domains (Fig. 11).

\section{Interpretation and discussion}

Theoretically, the chemical zonation in the larger garnet grains $(>1 \mathrm{~mm})$ could be due to changing physio-chemical conditions during crystal growth. The contacts between the cores and the particularly Fe-rich rims are, however, highly irregular, often patchy and in few cases show a spatial connection to fractures within the grains (Fig. 4c, d). Therefore, it is concluded that the Fe-rich domains are not the product of prograde garnet growth but of diffusional alteration from the exterior into the rims of the garnet grains. A potential $\mathrm{Fe}$ source for this alteration could be the break-down of magnetite, which occurs only as a relict phase. The observed contrast between a heterogeneous $\mathrm{Fe}$ - and the uniform $\mathrm{Mn}$ and $\mathrm{Ca}$-distribution in garnet is in agreement with the typical diffusive behavior of elements in garnet at high temperature metamorphic conditions (Caddick et al. 2010). Although the long-term high-temperature history of the ore district would make complete diffusional homogenization of garnet likely, the observed zonation with respect to Fe points at very low fluid/rock ratios, which markedly decrease diffusion rates (Florence and Spear 1995). Such low fluid/rock ratios are supported by the local layer-to-layer variations in oxygen and HF fugacity developed during metamorphism (Frimmel 1993; Stalder and Rozendaal 2005a). 
Fig. 9 Photomicrographs of representative samples affected by phyllic alteration. $\mathbf{a}+\mathbf{b}$ Sulfide rich vein. $\mathbf{c}+\mathbf{d}$ Alternation of coarse- and fine-grained alteration domains. $\mathbf{e}+\mathbf{f}$ Contact between domains of different grain size. a, c, e transmitted light, b, $\mathbf{d}$, f reflected light images. Garnet-apatite ore from drill core GPFD051 (Gamsberg deposit). $\mathrm{Ms}=$ muscovite, $\mathrm{Po}=$ Pyrrhotite, $\mathrm{Py}=$ Pyrite, $\mathrm{Qz}=$ quartz, $\mathrm{Ser}=$ sericite, $\mathrm{Sp}=$ sphalerite
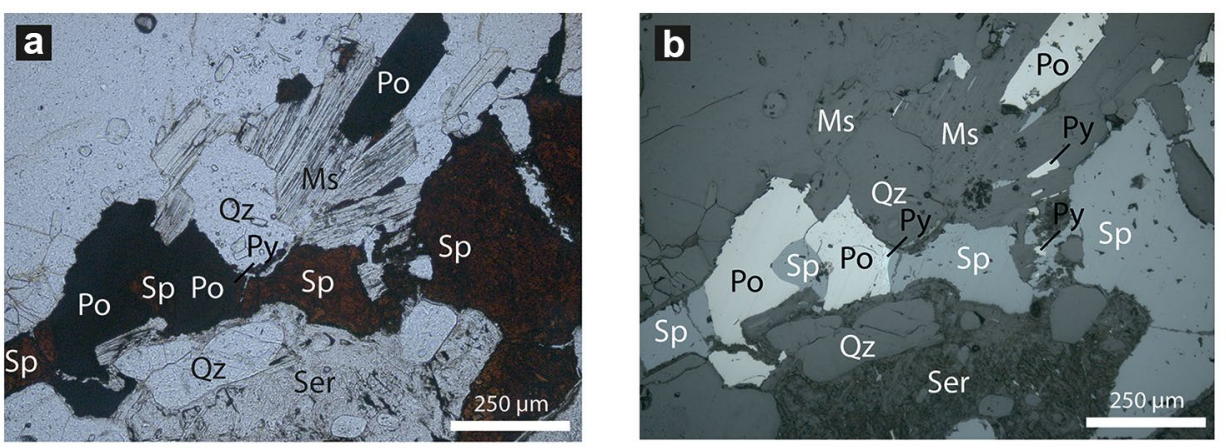

$\mathrm{Qz}+\mathrm{Ser}+\mathrm{Sp}$
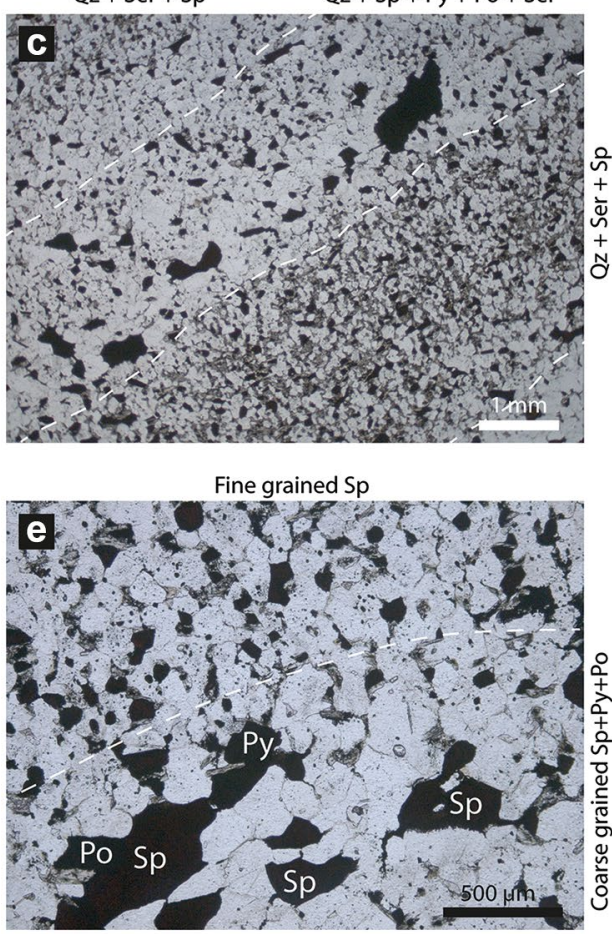
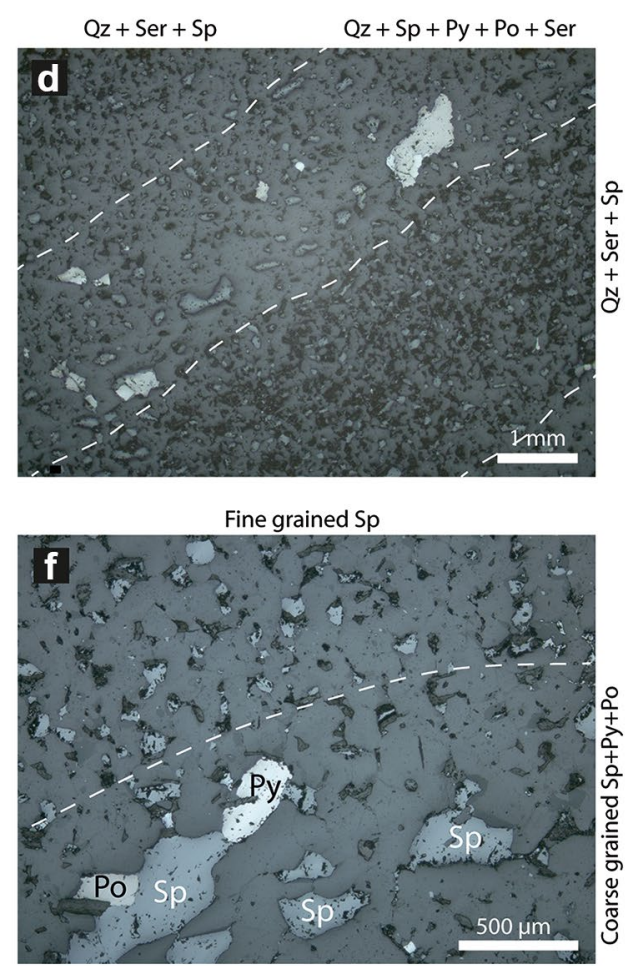

Apart from the above-mentioned variations in chemistry, the strong contrast between size and quantity of sulfide inclusions in the two garnet domains speaks for different degrees of dissolution and reprecipitation. The primary sulfide inclusions in the rims of the garnet grains dissolved and reprecipitated to fewer but larger inclusions (typically $>25 \mu \mathrm{m}$ ), while the sulfide inclusions within the relic core areas remained small (typically $<15 \mu \mathrm{m}$ ) and underwent this process to a lesser extent. The prominent segregation of Fe-rich sphalerite ( $\mathrm{Sp}-\mathrm{C}$ ) into Fe-poor sphalerite $(\mathrm{Sp}-\mathrm{R})$ and $\mathrm{Zn}$-rich pyrite (Py-R), which goes along with the change in garnet chemistry and the change in inclusion size, is best explained by the addition of sulfur to the inclusions of the altered zones (e.g. Hannington and Scott 1989). The fact that all three characteristics of the garnet and its inclusions show a perfect spatial correlation indicates that they are most likely products of the same process. The plots of $\mathrm{Fe}$ and Mn vs. Zn show that the chemistry of the texturally late sphalerite in the vicinity of the garnet grains $(\mathrm{Sp}-\mathrm{H})$ can be seen as a continuation of this sulfidation process. In fact, there are smooth transitions between the Fe-, $\mathrm{Mn}-$, and $\mathrm{Zn}$-contents in all three sphalerite types.

Our findings are best explained by infiltration of a S-rich metamorphic fluid. As the garnet grains acted as a fluid barrier and the crystallization of pyrite buffered the S-activity in the interior of the grains (e.g. Scott 1983; Hannington and Scott 1989), different zones developed within these garnet grains. At the outside of a given grain, a marginal zone formed under a relatively high, though overall still low fluid/ rock ratio and high S-fugacity, which caused metamorphic sulfide recrystallization to larger inclusions and the segregation of sulfides with lower metal/sulfur-ratios. The fluid/ rock-ratio in the core zones was even much lower and the fluid reaching the interior was already S-buffered by the crystallization of pyrite in the rim. Where no fluid reached the interior of the garnet, core zones with their original 


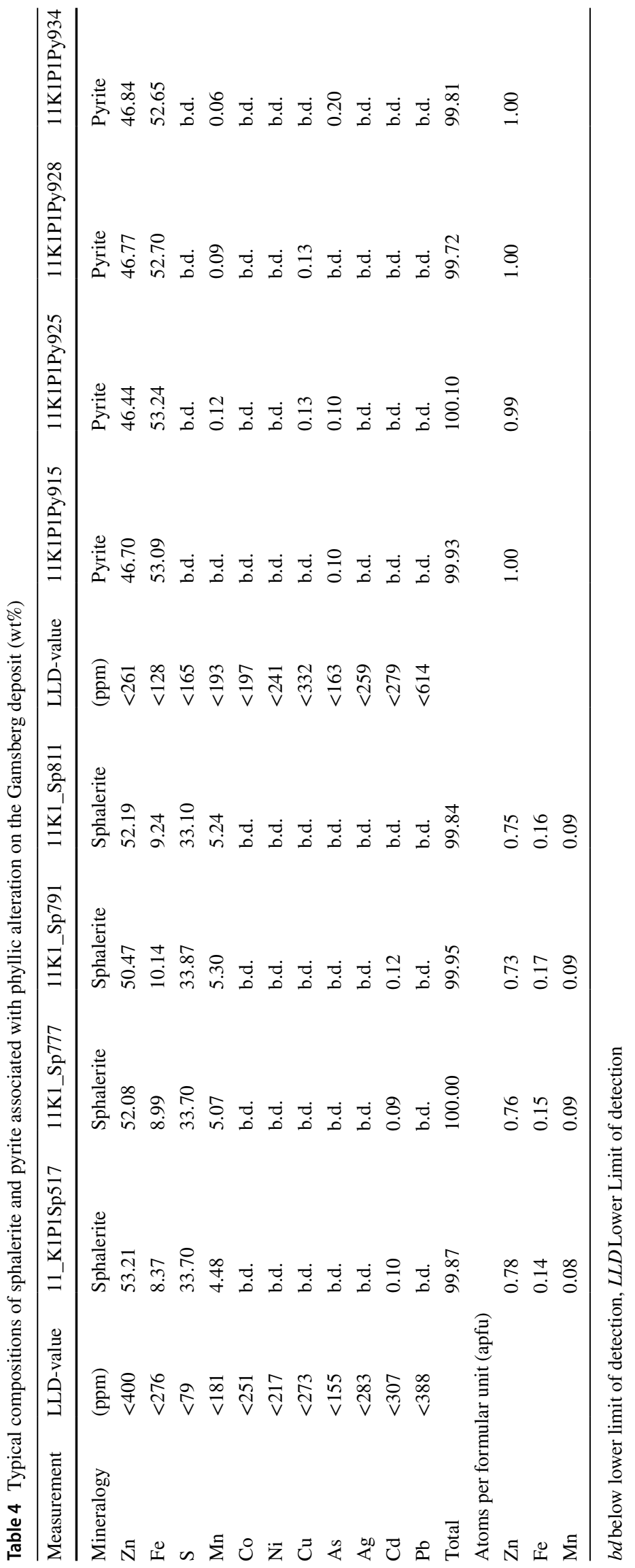


Fig. 10 a Crossed polarized transmitted light image of sphalerite associated with a sulfide-rich vein ( $\mathrm{Sp}-\mathrm{cg})$;

b, $\mathbf{c}$ and $\mathbf{d}$ Relative element abundance map of $\mathrm{Zn}, \mathrm{Mn}$ and K. Garnet-apatite ore from drill core GPFD051 (Gamsberg deposit)

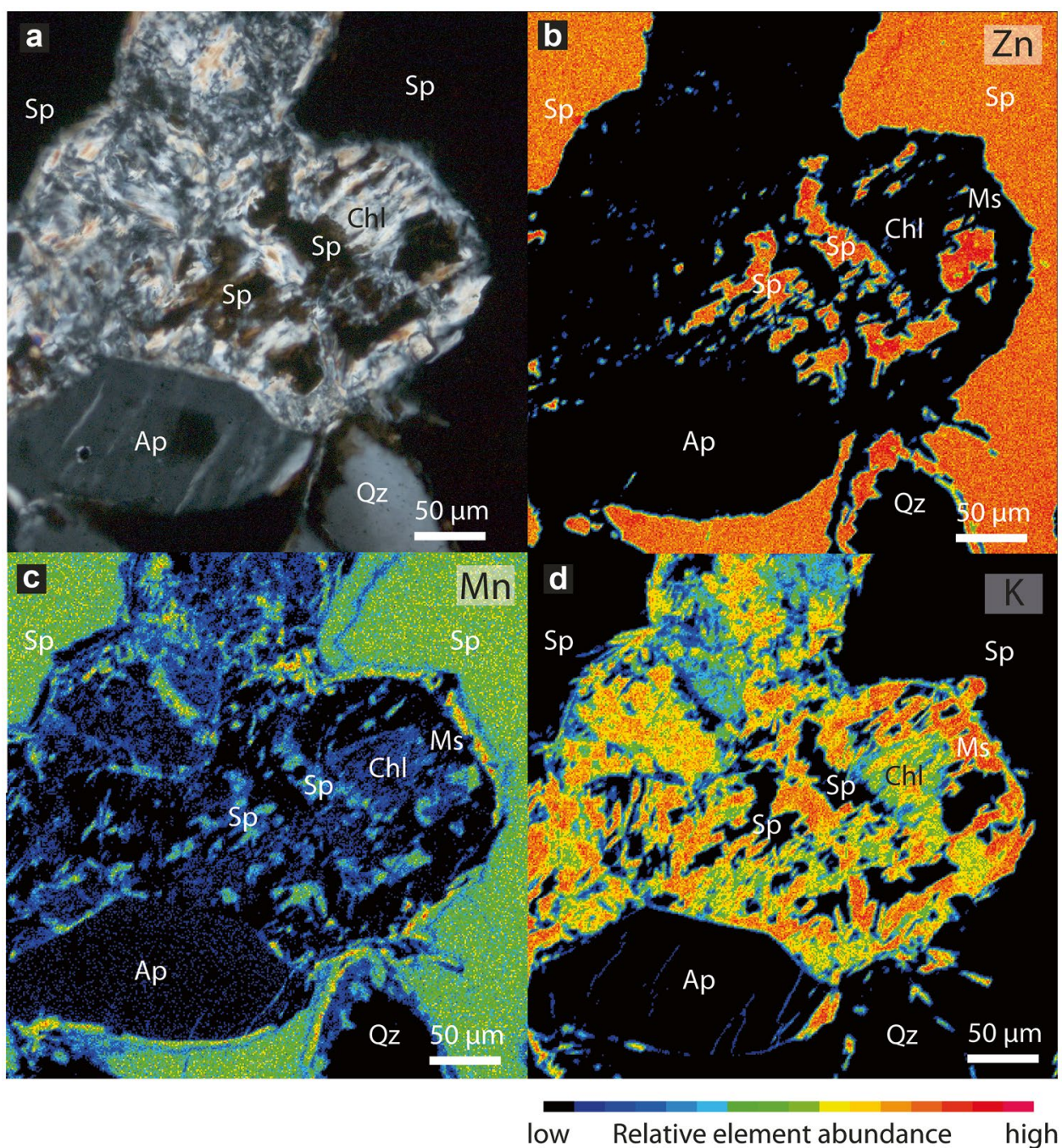

chemical characteristics survived in spite of the protracted high-grade metamorphic history.

The driving force for the chemical differences between sphalerite types was the growth of pyrite in the inclusions. The significantly lower Fe- and Mn-contents in the recrystallized sphalerite (Sp-R) reflect the growth of Mn-rich pyrite (Py-R) at its expense. Theoretically, the texturally late sphalerite $(\mathrm{Sp}-\mathrm{H})$ should have crystallized under maximum fluid/rock ratio because it was not surrounded by a fluid-barrier and this is indeed indicated by the chemistry of this sphalerite generation near the garnet grains $(\mathrm{Sp}-\mathrm{H})$ (Fig. 5). The fact that this Sp-H sphalerite is chemically uniform on a centimeter-scale but reveals significant chemical differences between drill cores (Fig. $5 \mathrm{a}+\mathrm{b}$ ) on a scale of tens of meters reflects highly variable fluid/rock ratio and/ or sulfur activity on the latter scale and precludes pervasive retrograde metamorphic fluid flow on a deposit scale. These observations are supported by those of McClung and Viljoen (2011), who described a wide compositional range (71 \pm 3.4 to $95 \pm 4.9 \mathrm{~mol} \% \mathrm{ZnS}$ ) for sphalerite filling open spaces in the Gamsberg deposit. Seemingly, this sphalerite type is the product of very short-range sulfide remobilization of pre-existing, chemically heterogenous sulfides. All three sphalerite types have very similar $\mathrm{Cd}$ concentrations (c. $0.07 \mathrm{wt} \%$ ), whereas $\mathrm{Cd}$ is below the detection limit in the associated pyrite. This indicates that its concentration in the different sphalerite types was not affected by the cyrstallisation of pyrite but is an earlier feature, which speaks for a close genetic connection between those sphalerite types.

Independent evidence of metamorphic sulfidation of base metal minerals in the deposit comes from the graphictextured intergrowths of sphalerite and pyrite. These show remarkable similarities with quenched sulfide melt textures (see Mavrogenes et al. 2001). However, the possibility of partial melting of the sulfidic ore in Aggeneys had been discussed previously for the Broken Hill deposit a few kilometers further west (Bailie and Reid 2005). The sulfides in the graphic-textured aggregates do not show, however, any enrichment in metals with a low melting-point, such as $\mathrm{Ag}$, As and $\mathrm{Cd}$, which is a common feature of sulfidic 


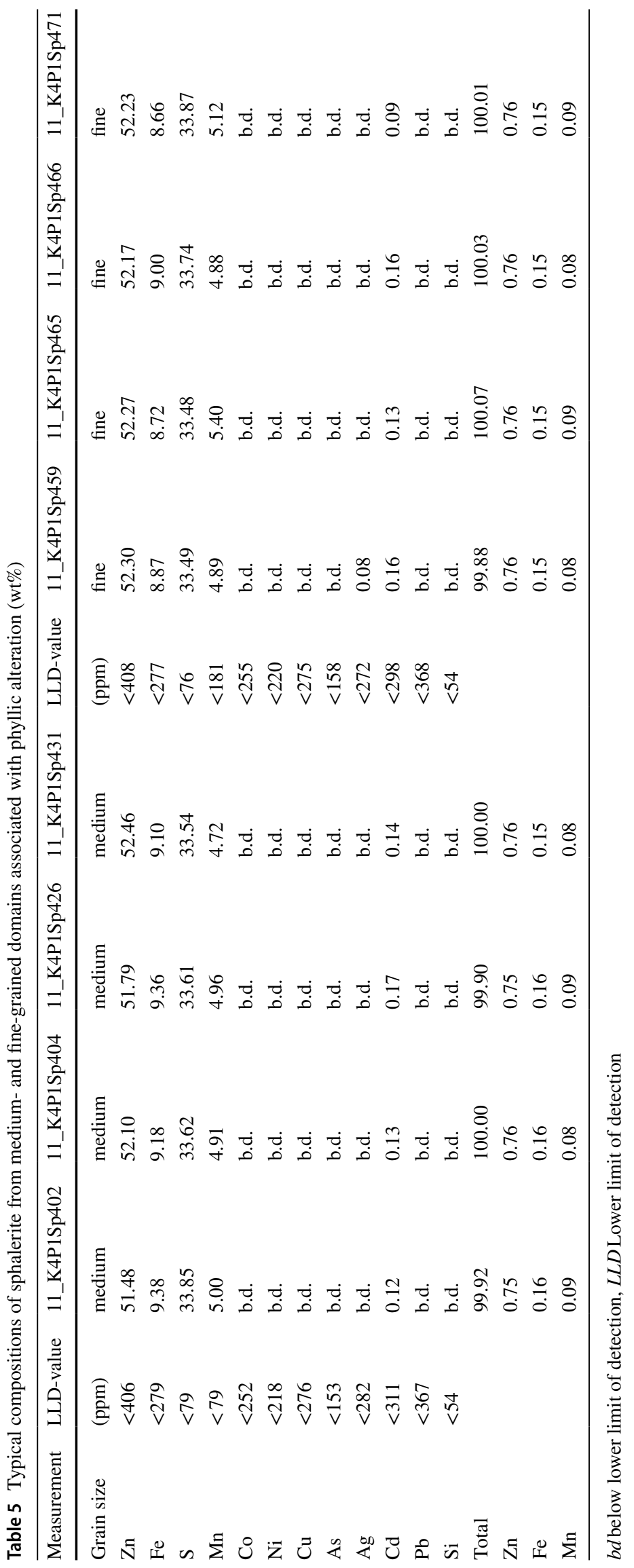


Fig. 11 Various element plots of sphalerite from various textural positions within the zones affected by phyllic alteration; garnet-apatite ore from the Gamsberg deposit
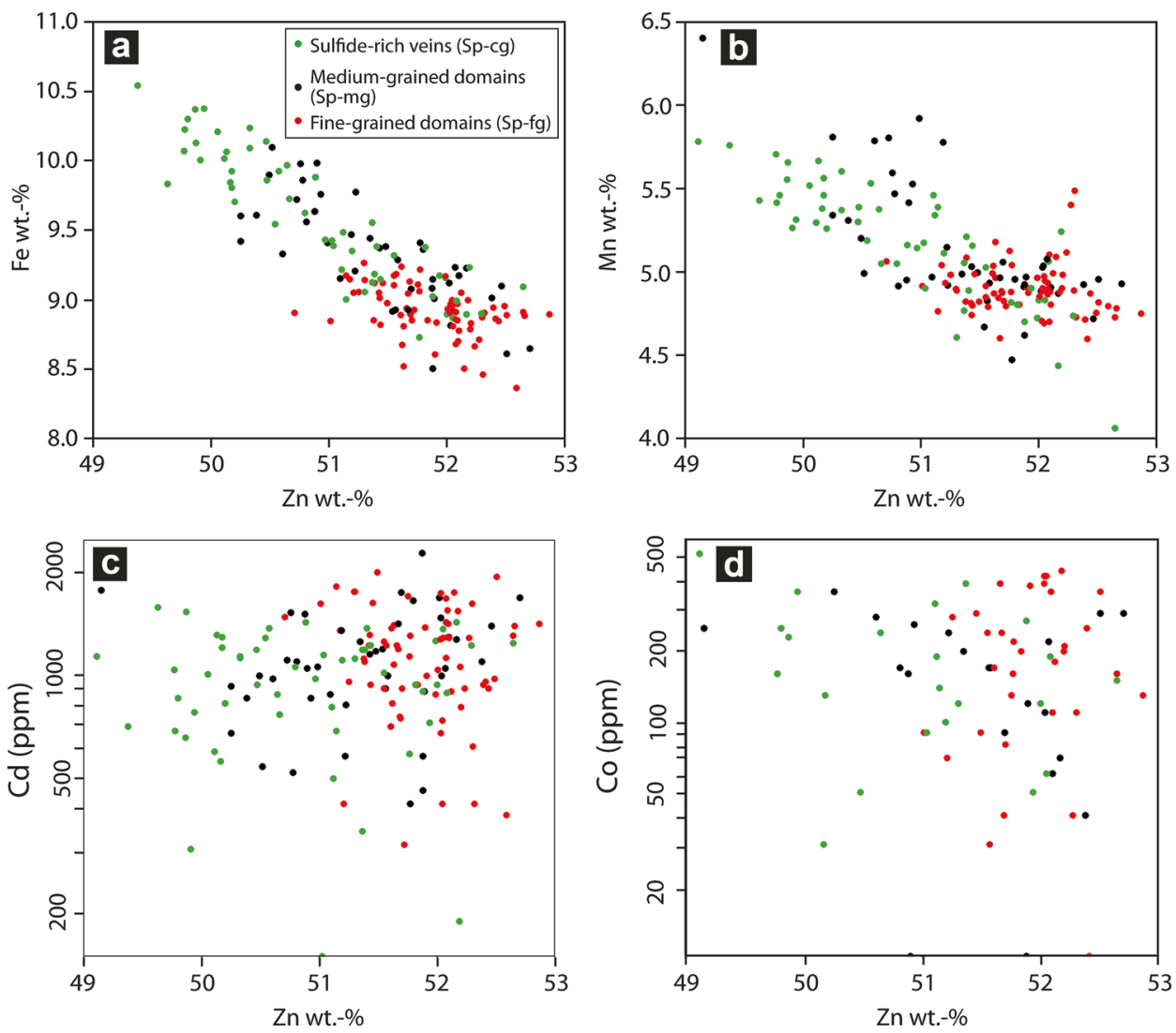

melts (Frost et al. 2002). Whereas the background concentrations of $\mathrm{Ag}$ and As are very low in the sulfides of the deposit, at least $\mathrm{Cd}$ is present in significant amounts and could have been concentrated if sulfide melting had taken place. However, no evidence of this could be found. Furthermore, graphic-textured aggregates with very few exceptions consist exclusively of sphalerite and pyrite, both of which are very poor in trace elements. Consequently, the melting point for those aggregates would be very high. Only a few graphic-textured sulfide aggregates also contain magnetite. Such magnetite grains occur in isolation within the sulfide aggregates and display irregular grain boundaries that indicate their relict nature. In places, graphic-textured aggregates show clear signs of replacement of pyrrhotite and magnetite by pyrite and sphalerite. Pyrite tends to occur as large euhedral crystals, especially where it replaced pyrrhotite (e.g. Fig. 6c, d), which speaks for stable growth conditions and against quenching. The high-angle orientation of the segregated elongated pyrite and sphalerite to the nearest grain boundary makes it highly likely that the segregation process proceeded from this outer surface into the grain (e.g. Fig. 6c, d). The elongated shape of the individual crystals is comparable to graphic textures in granites and thus interpreted as product of slow or limited lateral diffusion along the crystal-growth front (London 2009). This could be the product of low availability of fluid and/or low temperatures, which both hinder diffusion.

Other sulfidation features along fluid pathways, like fractures, show a smoother transition between sulfides with high- and low metal/sulfur-ratio. In the domains of strong phyllic alteration, the marked grain-size gradients and sulfide mineralogy both indicate different fluid/rock ratios. The finest grained domains are likely to represent those with lowest fluid/rock ratio, inhibiting crystal growth (e.g. Tullis and Yund 1982). Sphalerite, which is the only sulfide present in these domains, has Fe $(8.92 \pm 0.19 \mathrm{wt} \%)$ and $\mathrm{Mn}(4.9 \pm 0.15 \mathrm{wt} \%)$ contents similar to the sphalerite inclusions in the relic core zones of garnet (Fe: $7.64 \pm 1.19$ wt $\%$ and $\mathrm{Mn}: 3.00 \pm 0.87 \mathrm{wt} \%)$. We deduce, therefore, that the two sphalerite types are genetically related.

The more complex sulfide paragenesis (sphalerite + pyrite + pyrrhotite) in the medium-grained domains is probably the product of recrystallization in the presence of a fluid with a high Fe-content and a sulfur activity buffered by pyrite-pyrrhotite (Craig and Vokes 1983). Similarly, the high $\mathrm{Fe}$ - (and Mn-) contents in the coarsest grained sphalerite in veins within the phyllic alteration zone can be explained. As these veins are associated with chlorite and muscovite, they must be related to fluid migration on the retrograde metamorphic path. 
Previous studies on the sulfur isotopic composition of the Aggeneys-Gamsberg ore district (e.g. von Gehlen et al. 1983; McClung et al. 2007) revealed a distinct increase in $\delta^{34} \mathrm{~S}$ for the sulfides from Black Mountain in the west $\left(\delta^{34} \mathrm{~S}=16.0 \pm 1.6 \%\right.$ ) to Gamsberg in the east $\left(\delta^{34} \mathrm{~S}=29.9 \pm 1.0 \%\right.$; $)$. This had been explained by synsedimentary sulfide formation in several sub-basins with anomalous highly evolved seawater sulfate as $\mathrm{S}$ source in the eastern basins (Foukes 2014). And indeed, the $\delta^{34} S$ ratios reported for Gamsberg are fairly close to the global average for Mesoproterozoic sulfates (c. $24 \%$; Fike et al. 2015), which indicates a strong connection between those and the sulfur content of the deposit.

Based on our new results, the observed trend in $\delta^{34} S$ could be the product of variations in the amount of sulfur-rich fluid that reacted with the already metamorphosed rocks and/or a consequence of differences in the oxidation state of the precursor. Considering its stratigraphic position right below the pre-Klondikean unconformity and its $\mathrm{Zn}$-dominated base metal content, the Gamsberg deposit probably experienced the most intense pre-Klondikean weathering-induced oxidation at the time of the hiatus (Höhn et al. 2020) and consequently the most intense resulfidation thereafter. In that case, the $\delta^{34} \mathrm{~S}$ ratios of its sulfides should not describe the primary but rather the metamorphic sulfur source.

The stratigraphic position of the hiatus, which most probably caused the oxidation of the ore, between the Okiepian (1210-1180 Ma) and the Klondikean (1040-1020 Ma; Cornell et al. 2009) metamorphic events narrows down the potential sulfur sources. The rocks in the footwall of the unconformity between the Koeris and the Hotson Formation experienced temperatures and pressures of c. $850{ }^{\circ} \mathrm{C}$ and 4-6 kbar during Okiepian metamorphism and thus had been effectively devolatilized prior to oxidation. They could not have been a significant sulfur source. In contrast, the shallow-water rift sediments of the Koeris Formation were deposited after the hiatus and might have included evaporites before the high-grade Klondikean metamorphism. Even though high-grade meta-evaporites are hard to identify, calc-silicate rocks at the base of the Koeris Formation at Gamsberg (Praekelt et al. 2006) could well represent former evaporite beds. Be that as it may, depending on the pre-metamorphic oxidation state a more or less pervasive fluid flow would be necessary, which is in conflict with local observations of low fluid/rock ratios (Frimmel 1993; Stalder and Rozendaal 2005a).

Alternatively, the postulated sulfates might have formed during the pre-Klondikean oxidation. The formation of $\mathrm{Zn}$ sulfate is a key factor in the mineralization of supergene base metal deposits (Boni and Large 2003). For a Zn-dominated base metal enrichment, this can happen without significant sulfur loss. An unusually high graphite content in the
Gamsberg ore (Stalder 2004) could have caused subsequent thermochemical sulfate reduction.

Under the influence of the postulated $\mathrm{H}_{2} \mathrm{~S}$-rich fluids, prograde metamorphic re-equilibration and recrystallization of base metal-sulfates, -silicates, -oxides and -hydroxides should have formed a paragenesis of high metal/sulfurratio sulfides, like pyrrhotite and sphalerite (Aubourg et al. 2019; Ejtemaei et al. 2014) together with magnetite (Pilchin 2010). Sulfidation textures from such a prograde path are, however, very unlikely to survive a typical metamorphic development with extensive recrystallization under peak metamorphic conditions. We suspect, therefore, that the retrograde sulfidation described in this study was merely the continuation of sulfidation that had commenced already on the prograde metamorphic path. The graphic-textured aggregates, sulfidation products in close spatial association to fractures and the phyllic alteration can all be assigned to temperatures $<450{ }^{\circ} \mathrm{C}$. The phyllic alteration represents the highest temperatures and highest fluid/rock ratios with a well-buffered fluid close to the boundary of the stability fields of pyrite and pyrrhotite. This was followed by sulfidation along fractures and then the development of the graphic sulfide textures, reflecting the lowest fluid/rock ratio and lowest metamorphic temperatures. Only under these late metamorphic conditions, the well-documented high sulfidation state with Fe-disulfides like pyrite replacing peak metamorphic pyrrhotite and magnetite (e.g. Qian et al. 2009) was reached. The observed sulfidation features are still preserved because they formed under decreasing temperatures on the retrograde path. If they had formed on the prograde path, they would not have survived bearing in mind the overall long-lasting high-temperature history of the area.

Even though the amount of fluid liberated during retrograde metamorphism is generally much lower than along the prograde path (e.g. Yardley et al. 2000), uplift and exhumation of metamorphic rocks can trigger locally higher fluid accessibility by fracturing of wallrocks (Henley et al. 1976; Vry et al. 2010). These processes could have provided the fluids necessary for the retrograde metamorphic small-scale continuation of the sulfidation.

The suggested metamorphic sulfidation fills a hitherto unexplained gap in the complex metallogenetic history of the Aggeneys-Gamsberg ore district. The position of the orebodies only a few meters below a major unconformity and $\mathrm{Cu}$ isotopic characteristics of the orebodies from Black Mountain and Broken Hill (Höhn et al. 2020) indicate a pre-Klondikean oxidation event. A phase of strong oxidative chemical weathering on a pre-Klondikean paleosurface is supported by the widespread occurrence of peraluminious rocks around Aggeneys (Willner et al. 1990), the high quantities of base metals in silicates and oxides (Walters 
1998), and the unusually strong enrichment in $\mathrm{Mn}$ in this area (McClung and Viljoen 2011). The metamorphic sulfidation suggested in this study provides the link between this oxidation event and the currently reduced, high sulfidation state of the deposits in the Aggeneys-Gamsberg ore-district.

\section{Conclusions}

- The data presented in this study show that graphic textured sulfides previously interpreted as quenched sulfidic melts are more likely a late, low-temperature metamorphic sulfidation feature. This explains not only the lack of elements associated with low-melting point in these sulfides but also the preservation of those textures, which in case of a quenched sulfidic melt should have been destroyed in the course of metamorphic recrystallization under high-grade conditions.

- The data obtained from the analyses of sulfide inclusions in garnet provide further evidence of retrograde sulfidation. In this context, the microfracture-related replacement of pyrrhotite by pyrite may also speak in favor of this process. Assuming a typical metamorphic history, this process can be seen as continuation of an even more intense prograde sulfidation, when the vast majority of $\mathrm{H}_{2} \mathrm{~S}$-rich fluids was liberated, possibly from sulfates in the oxidation zone or from meta-evaporites in the overlying Koeris Formation. Considering the stratigraphic position of the sulfidic orebodies of the Aggeneys-Gamsberg ore district only meters below a major pre-Klondikean unconformity, it is highly probable that they had been exposed to oxidation during this pre-Klondikean hiatus. This opens up the possibility that the metamorphic sulfidation suggested here affected not only previously existing sulfides with a lower sulfidation state but also supergene alteration products such as base metal silicates, -oxides and -hydroxides. Such reduction/sulfidation of previously oxidized base metal minerals would also explain recently obtained $\mathrm{Cu}$ isotope ratios of the different deposits presented by Höhn et al. (2020).

- Our findings suggest that sulfur-rich metamorphic fluids were able to (re-)-sulfidize base metal-rich rocks on a deposit scale and thereby to camouflage previous oxidation as expected beneath a chemically weathered land surface. This sheds new light on the metallogenetic history of high-grade metamorphic sulfide deposits, especially Broken Hill-type deposits, which are full of apparent redox-inconsistencies and in some cases show a base metal distribution that cannot be explained solely by the metamorphism of a former SEDEX deposit.
Supplementary information The online version contains supplementary material available at https://doi.org/10.1007/s00710-021-00764-w.

Acknowledgements We thank Vedanta Resources for granting us access to their facilities and drill core and P. Späthe for the preparation of high-quality (polished) thin sections. The analytical work was funded by the Department of Geodynamics and Geomaterials Research in the University of Würzburg.

Authors' contributions The project was conceived by HEF based on initial studies in the 1990s. Field work around Aggeneys was conducted by all three authors together. All analyses were conducted by SH who also wrote the draft manuscript. WP contributed with his experience of the local geological setting. HEF helped in the interpretation and revised the original manuscript.

Funding Open Access funding enabled and organized by Projekt DEAL. Vedanta Zinc International provided sample material.

Data availability All data presented in the text of the article are fully available without restriction from the first author upon request.

Code availability Code availability is not applicable.

\section{Declarations}

Conflicts of interest The authors declare that they have no competing interests.

Open Access This article is licensed under a Creative Commons Attribution 4.0 International License, which permits use, sharing, adaptation, distribution and reproduction in any medium or format, as long as you give appropriate credit to the original author(s) and the source, provide a link to the Creative Commons licence, and indicate if changes were made. The images or other third party material in this article are included in the article's Creative Commons licence, unless indicated otherwise in a credit line to the material. If material is not included in the article's Creative Commons licence and your intended use is not permitted by statutory regulation or exceeds the permitted use, you will need to obtain permission directly from the copyright holder. To view a copy of this licence, visit http://creativecommons.org/licenses/by/4.0/.

\section{References}

Aubourg C, Jackson M, Ducoux M, Mansour M (2019) Magnetite-out and pyrrhotite-in temperatures in shales and slates. Terra Nova 31:534-539

Bailie R, Armstrong A, Reid D (2007) The Bushmanland Group supracrustal succession, Aggeneys, Bushmanland, South Africa: Provenance, age of deposition and metamorphism. S Afr J Geol 110:59-86

Bailie RH, Reid DL (2005) Ore textures and possible sulphide partial melting at Broken Hill, Aggeneys, South Africa I: Petrography. S Afr J Geol 108:51-70

Bial J, Büttner SH, Schenk V, Appel P (2015) The long-term hightemperature history of the central Namaqua Metamorphic Complex: Evidence for a Mesoproterozoic continental back-arc in southern Africa. Precambrian Res 268:243-278 
Boni M, Large D (2003) Nonsulfide Zinc Mineralization in Europe: An Overview. Economic Geology 98(4) 715-729 https://doi.org/ 10.2113/gsecongeo.98.4.715

Caddick MJ, Konopásek J, Thompson AB (2010) Preservation of garnet growth zoning and the duration of prograde metamorphism. J Petrol 51:2327-2347

Cawood TK, Rozendaal A (2020) A multistage genetic model for the metamorphosed Mesoproterozoic Swartberg Base Metal Deposit, Aggeneys-Gamsberg Ore District, South Africa. Econ Geol 115:1021-1054

Clifford TN, Barton ES, Stern RA, Duchesne J-C (2004) U-Pb zircon calendar for Namaquan (Grenville) crustal events in the granulite facies terrane of the O'okiep copper district of South Africa. J Petrol 45:669-691

Colliston WP, Schoch AE, Cole J (2017) The Grenvillian Namaqua Fold Belt adjacent to the western Kaapvaal Craton: 2. Archaean Craton and Supercontinent connections. Precambrian Res 300:289-314

Colliston WP, Schoch AE, Praekelt HE (2012) Stratigraphy of the Mesoproterozoic Aggeneys Terrane, Western Namaqua Mobile Belt, South Africa. S Afr J Geol 115:449-464

Cornell DH, Pettersson Å, Whitehouse MJ, Scherstén A (2009) A new chronostratigraphic paradigm for the age and tectonic history of the Mesoproterozoic Bushmanland ore district, South Africa. Econ Geol 104:385-404

Cornell DH, Thomas RJ, Moen HFG, Reid DL, Moore JM, Gibson RL (2006) The Namaqua-Natal province. In: Johnson MR, Anhaeusser CR, Thomas RJ (eds) The Geology of South Africa. Geological Society of South Africa, Johannesburg, pp 325-379

Craig JR, Vokes FM (1983) The metamorphism of pyrite and pyritic ores: an overview. Mineral Mag 57:3-18

Ejtemaei M, Gharabaghi M, Irannajad M (2014) A review of zinc oxide mineral beneficiation using flotation method. Adv Colloid Interface Sci 206:68-78

Fike DA, Bradley AS, Rose CV (2015) Rethinking the ancient sulfur cycle. Annu Rev Earth Planet Sci 43:593-622

Florence FP, Spear FS (1995) Intergranular diffusion kinetics of Fe and $\mathrm{Mg}$ during retrograde metamorphism of a pelitic gneiss from the Adirondack Mountains. Earth Planet Sci Lett 134:329-340

Foulkes SE (2014) New geochemical constraints on the genesis of the Gamsberg zinc deposit, Namaqualand metamorphic province, South Africa. Unpubl. MSc thesis, Dept. of Geology, Rhodes University

Frimmel HE, Hoffmann D, Moore JM (1993) Preservation of syn-depositional geochemical characteristics of the Broken Hill massive sulphide deposits, South Africa, during upper amphibolite facies metamorphism. In: Fenoch Hach-Ali P, Torres-Ruiz J, Gervilla F (eds) Current Research in Geology Applied to Ore Deposits. University of Granada, Spain, pp 303-306

Frimmel HE, Hoffmann D, Watkins RT, Moore JM (1995) An Fe analogue of kinoshitalite from the Broken Hill massive sulfide deposit in the Namaqualand Metamorphic Complex, South Africa. Am Mineral 80:833-840

Frost BR, Mavrogenes JA, Tomkins A (2002) Partial melting of sulfide ore deposits during medium- and high-grade metamorphism. Canad Mineral 40:1-18

Hannington MD, Scott SD (1989) Sulfidation equilibria as guides to gold mineralization in volcanogenic massive sulfides: Evidence from sulfide mineralogy and the composition of sphalerite. Econ Geol 84:1979-1995

Henley RW, Norris RJ, Paterson CJ (1976) Multistage ore genesis in the New Zealand Geosyncline. A history of post-metamorphic lode emplacement. Miner Deposita 11:180-196

Höhn S, Frimmel HE, Debaille V, Westley P (2020) Pre-Klondikean oxidation prepared the ground for Broken Hill-type mineralization in South Africa. Terra Nova 33:168-173
Janoušek V, Farrow CM, Erban V (2006) Interpretation of whole-rock geochemical data in igneous geochemistry: Introducing Geochemical Data Toolkit (GCDkit). J Petrol 47:1255-1259

Large R, Bull S, Selley D, Yang J, Cooke D, Garven G, McGoldrick $P$ (2002) Controls on the formation of giant stratiform sedimenthosted $\mathrm{Zn}-\mathrm{Pb}-\mathrm{Ag}$ deposits: with particular reference to the north Australian Proterozoic. In: Cooke DR and Pongratz J (eds) Giant Ore Deposits: Characteristics, Genesis and Exploration. CODES Special Publication 4. University of Tasmania, Australia, pp $107-150$

Lipson RD (1990) Lithogeochemistry and origin of metasediments hosting the Broken Hill deposit, Aggeneys, South Africa, and implications for ore genesis. Unpubl. PhD thesis, University of Cape Town

Locock AJ (2008) An Excel spreadsheet to recast analyses of garnet into end-member components, and a synopsis of the crystal chemistry of natural silicate garnets. Comput and Geosci 34:1769-1780

London D (2009) The origin of primary textures in granitic pegmatites. Canad Mineral 47:697-724

McClung CR, Gutzmer J, Beukes NJ, Mezger K, Strauss H, Gertloff E (2007) Geochemistry of bedded barite of the Mesoproterozoic Aggeneys-Gamsberg Broken Hill-Type district, South Africa. Miner Deposita 42:537-549

McClung CR, Viljoen F (2011) A detailed mineralogical assessment of sphalerites from the Gamsberg zinc deposit, South Africa: The manganese conundrum. Miner Eng 24:930-938

Mavrogenes JA, MacIntosh IW, Ellis DJ (2001) Partial melting of the Broken Hill galena-sphalerite ore: experimental studies in the system PbS-FeS-ZnS-(Ag2S). Econ Geol 96:205-210

Philibert J (1963) A method for calculating the absorption correction in electron probe microanalysis. In X-Ray Optics and X-Ray Microanalysis. In: Pattee HH, Cosslett VE, Engström A (eds) Proceedings of the 34rd International Symposium on X-Ray Optics and X-Ray Microanalysis, Academic Press, New York, pp. 379-392

Philibert J, Tixier R (1968) Electron penetration and the atomic number correction in electron probe microanalysis. J Phys D Appl Phys $1: 685-694$

Pilchin A (2010) Magnetite: the story of the mineral's formation and stability. In: Angrove DM (ed) Magnetite: Structure, Properties and Applications. Nova Science Publishers, New York, pp 1-99

Praekelt HE, Colliston WP, Schoch AE (2006) Lithostratigraphy of the Koeris Formation (Bushmanland Group). Lithostratigraphic Series 41, Council for Geoscience, Pretoria

Qian G, Pring A, Brugger J, Skinner W, Chen G (2009) Replacement of magnetite by pyrite under hydrothermal conditions. J Geochem Explor 101:83

Reed SJB (1965) Characteristic fluorescence corrections in electronprobe microanalysis. Br J Appl Phys 16:913-926

Rozendaal A (1986) The Gamsberg zinc deposit, Namaqua District. In: Anhausser CR, Maske S (eds) Mineral Deposits of Southern Africa, vol II. Geological Society of South Africa, Johannesburg, pp 1477-1488

Rozendaal A, Rudnick T-K, Heyn R (2017) Mesoproterozoic base metal sulphide deposits in the Namaqua sector of the NamaquaNatal Metamorphic Province, South Africa: a review. S Afr J Geol 120:153-186

Ryan PJ, Lawrence AL, Markl RD, Moore JM, Paterson A, Stedman DP, van Zyl D (1986) The Aggeneys base metal sulfides, Namaqualand District. In: Anhaeusser CR, Maske S (eds) Mineral Deposits of Southern Africa, vol II. Geological Society of South Africa, Johannesburg, pp 1447-1473

Sangster DF (2020) Evidence that Broken Hill-type Pb-Zn deposits are metamorphosed SEDEX deposits. Miner Deposita 55:1263-1270

Scott SD (1983) Chemical behavior of sphalerite and arsenopyrite in hydrothermal and metamorphic environments. Mineral Mag 47:427-435 
Spry PG, Teale GS (2021) A classification of Broken Hill-type deposits: A critical review. Ore Geol Rev 139:103935

Stalder M (2004) Petrology and mineral chemistry of sulphide ores and associated metalliferous rocks of the Gamsberg $\mathrm{Zn}-\mathrm{Pb}$ deposit, South Africa: Implications for ore genesis and mineral exploration. Unpubl. PhD thesis, University of Stellenbosch

Stalder M, Rozendaal A (2004) Apatite nodules as an indicator of depositional environment and ore genesis for the Mesoproterozoic Broken Hill-type Gamsberg Zn-Pb deposit, Namaqua Province, South Africa. Miner Deposita 39:189-203

Stalder M, Rozendaal A (2005a) Calderite-rich garnet and frankliniterich spinel in amphibolite-facies hydrothermal sediments, Gamsberg $\mathrm{Zn}-\mathrm{Pb}$ deposit, Namaqua Province, South Africa. Canad Mineral 43:585-599

Stalder M, Rozendaal A (2005b) Distribution and geochemical characteristics of barite and barium-rich rocks associated with the Broken Hill-type Gamsberg $\mathrm{Zn}-\mathrm{Pb}$ deposit, Namaqua Province, South Africa. S Afr J Geol 108:35-50

Tullis J, Yund RA (1982) Grain growth of quartz and calcite aggregates. J Geol 90:301-318
Von Gehlen K, Nielsen H, Chunnett I, Rozendaal A (1983) Sulphur isotopes in metamorphosed Precambrian $\mathrm{Fe}-\mathrm{Pb}-\mathrm{Zn}-\mathrm{Cu}$ sulphides and baryte at Aggeneys and Gamsberg, South Africa. Mineral Mag 47:481-486

Vry J, Powell R, Golden KM, Petersen K (2010) The role of exhumation in metamorphic dehydration and fluid production. Nat Geosci 3:31-35

Walters SG (1998) Broken Hill-type deposits. J Aust Geol Geophys 17:229-237

Whitney DL, Evans BW (2010) Abbreviations for names of rock-forming minerals. Am Mineral 95:185-187

Willner A, Schreyer W, Moore JM (1990) Peraluminous metamorphic rocks from the Namaqualand metamorphic complex (South Africa): Geochemical evidence for an exhalation-related, sedimentary origin in a Mid-Proterozoic rift system. Chem Geol 81:221-240

Yardley B, Gleeson S, Bruce S, Banks D (2000) Origin of retrograde fluids in metamorphic rocks. J Geochem Explor 69-70:281-285

Publisher's Note Springer Nature remains neutral with regard to jurisdictional claims in published maps and institutional affiliations. 